\title{
New frontiers in agricultural geography: transformations, food security, land grabs and climate change
}

\author{
Nuevas fronteras en la geografía agraria: transformaciones, \\ seguridad alimentaria, apropiación de tierras y cambio climático
}

\author{
Guy M. Robinson \\ guy.robinson@adelaide.edu.au \\ School of Social Sciences \\ University of Adelaide (Australia)
}

\begin{abstract}
Agriculture as a central focus of study featured prominently at several different times in the historical development of human geography, but it has also been an important contributor to the disciplinary transformation that has occurred since 1970. This essay outlines this more recent history, arguing that agricultural geography developed its own concepts and concerns, paralleling some of those within the wider discipline. It illustrates how in the past two decades attempts to examine changes occurring across the breadth of the agrifood system (from supply, to production, to consumption) have brought about a more issues-focused agricultural geography. There is discussion of the use of broad overarching concepts, which have conceived of changes to agriculture and the agri-food system in terms of episodic developments. This has seen recognition of different food regimes, acknowledging possible transitions from productivism to post-productivism to multifunctionality and perhaps neoproductivism. Having discussed these concepts, drawing extensively upon literature written in English, the essay then focuses on selected major problems or key issues to which agricultural geographers are currently contributing new insights, namely the closely related topics of food security, land grabs and adaptations to climate change.
\end{abstract}


Key words: agricultural geography; food regimes; productivism; multifunctionality; land grabs; climate change adaptation.

\section{Resumen}

La agricultura como foco central de estudio ha tenido un lugar destacado en diferentes momentos del desarrollo histórico de la geografía humana, pero también ha contribuido notablemente a la transformación de la disciplina que ha tenido lugar desde 1970. Este ensayo describe la historia más reciente de la geografía agraria. Se argumenta que la geografía agraria ha desarrollado sus propios conceptos y preocupaciones en paralelo a algunos de los de la disciplina más amplia. Se ilustrará cómo en las últimas dos décadas los intentos de examinar los cambios que se producen en todo el sistema agroalimentario (desde el suministro hasta la producción y el consumo) han provocado una geografía agraria más centrada en problemas concretos. Se discute el uso de conceptos generales amplios que han concebido los cambios en la agricultura y el sistema agroalimentario en términos de desarrollos episódicos. Esto implicaría reconocer diferentes regímenes alimentarios, de forma que se acepten posibles transiciones del productivismo al postproductivismo a la multifuncionalidad y tal vez al neo-productivismo. A través de una revisión bibliográfica en inglés, y después de discutir estos conceptos, el ensayo se enfoca en los principales problemas seleccionados o temas clave a los cuales los geógrafos agrarios aportan nuevos conocimientos, a saber, los temas estrechamente relacionados con la seguridad alimentaria, el acaparamiento de tierras y las adaptaciones al cambio climático.

Palabras clave: geografía agraria; regímenes alimentarios; productivismo; multifuncionalidad; apropiación de tierras; adaptación al cambio climático.

\section{Introduction: The evolution of agricultural geography}

Studies of agriculture by geographers have played an important part in the evolution of the discipline at several times in its history. Maps of the distribution of farms, crops and livestock played an important part in the construction of regional geographies in the 1920s and 1930s, and quantitative analysis of these distributions featured prominently in the so-called 'new' geography of the 1960s and 1970s. Cartographic and statistical sophistication accompanied this work (Coppock, 1976a; 1976b; Majoral, 1979a; 1979b), but the increasing concern with global processes has generated a broader canvas for study, supplanting the relatively narrow focus on charting and analysing the distribution of crops and livestock (Robinson, 2018b). In the 1970s and 80s, behavioural approaches in human geography included investigations of farmers' decision-making, the diffusion of agricultural innovations, and responses of individual farmers to economic stimuli (Burton, 2004; Morris \& Evans, 2004). Subsequently, geographical research on agricultural topics has broadened considerably, but increasingly engaging with issues of major consequence to society and to policy 
making. This has included work on climate change, food security, environmental impacts, technological advances and the changing role of agriculture within global development.

This essay examines some aspects of the evolution of this wider canvas for agricultural geography. Drawing primarily on work published in English, it chronicles the emergence of new frontiers within the subject as part of profound changes in the discipline, in which the lens of enquiry has shifted dramatically in scope and content. Emphasis is placed upon the way in which research has sought to encompass analysis across the breadth of the entire agri-food sector: from the various inputs to farming, such as seeds, fertilizers and machinery, to the production processes on farms to the 'downstream' activities of processing, wholesaling, retailing and consumption. This consideration of the wider agri-food system has moved attention away from the individual farmer, while acknowledging farms as part of the wider agrifood chain, itself embedded in a complex web of economic, social, cultural and political dimensions all impacting on farm-based production. This emphasis on the need to understand agriculture as part of the global agri-food system has presented new research challenges in which the work of geographers has often become part of multidisciplinary activity not only within the social sciences but spanning the interface between science and social science.

The initial engagement with the breadth of the agri-food system came through approaches in human geography that were labelled 'political economy' in recognition of its incorporation of Marxist-related content (Cloke, 1989). Pioneering work was done by Piers Blaikie (1985), whose research on the political economy of soil erosion in developing countries emphasized the social relations of production and their ramifications for land use. He conceptualized the farm household as having two kinds of social relations: the local and the global, with the latter increasingly assuming greater prominence. Indeed, the growing recognition of the significance of global linkages and networks has subsequently played a major role within agricultural geography, but without necessarily being tied to some of the more restrictive Marxist ideas that characterized the initial political economy approaches.

Within agricultural geography, there was a concern for four key elements (Marsden, 1988): 1) uneven development (whereby capital penetrated different regions at different rates); 2) geographical and historical specificity (which necessitated studies of particular locales to understand the process of uneven development); 3) examining the family farm (in which it was recognized that the basis of agricultural production differs from that of other sectors of the economy); and 4) the role of state policy (where governments have both supported the family farm but also permitted some penetration of agriculture by corporate capital) (see Ouma, 2016). The growth of agribusiness, agricultural restructuring, and the diversity of social relations and cultural practices which shape accumulation and regulation were the primary research foci in this approach. Distinctive variations in content occurred in different countries, so that in the United Kingdom (UK) agricultural geography was increasingly subsumed within the scope of a broader rural geography (Milbourne, 2016). In 
contrast, more distinctive and vibrant agricultural geographies have flourishised in the United States, France, and Germany (Chaléard \& Charvet 2004). In Spain one focus has been on changes to land use (Corbelle-Rico et al., 2012; Serra et al., 2014), but there has also been increasing engagement with the impacts of globalisation and rural transformation (e.g. Hernández Hernández et al., 2018; Massot-Marti, 2002; Molinero Hernando, 2016) as well as a concern for social aspects of farming (De los Ríos et al., 2016; Galdeano-Gómez et al., 2016).

During the 1990s there were several prominent critiques of political economy approaches, notably attacking its prime focus on production, macroeconomic factors and structural processes, rather than active decision-making by farm families (especially non-economic decisions by farmers regarding allocation of resources) (Robinson, 2004, pp. 36-52). Nevertheless, the attention being given to the broad agri-food sector prompted theorising about contemporary agricultural change across the sector. This involved work on food regimes, regulation theory, and a restatement of the "agrarian question", and it is these topics that essentially provide the springboard for the rest of this essay.

\section{Food regimes, productivism and post-productivism}

\subsection{Food regimes}

Agricultural geographers have presented their own interpretation of the episodic changes that featured strongly in Marx's writings, and which are associated with moves from one set of regulating structures to another. One conception of such changes has been food regimes, which link international relations of food production and consumption from the 1870s onwards to forms of accumulation and regulation under capitalist systems (McMichael, 2013). Three regimes are recognized: one from the 1870s to World War I, based on worldwide grain and meat production involving exports from family farms in the New World and linked to the rise of nation-states; the second from the 1920s to the 1980s (involving production of durable food for the mass market, decolonization, consumerism, and the growth of forward and backward linkages from agriculture); and a putative third from the 1990s, which emphasizes fresh, organic, and reconstituted foods linked to global restructuring (e.g. Ríos-Núñez \& Coq-Huelva, 2015). It also embraces the globalization of production and consumption, international regulation, and the growth of 'green' consumers (Robinson, 2018a). In this third regime globalization has often enabled regions in which 'traditional' commodities produced for the world market such as grain, wool and refrigerated meat, to introduce new commodities also intended for worldwide sales. The emergence of new wine regions in the New World is one such example (Perkins et al., 2015), now being emulated by wine production in China (Anderson \& Wittwer, 2015).

The food regimes overlap, and the third regime is still evolving as it includes oppositional forces such as globalization and sustainability, involving a complex and competing mixture of 
biotechnology, fast food, organic production, and consumption of locally-produced food (Guthman, 2004). It also embraces extensions of technology from the second regime, including biotechnology and the use of chemicals, e.g., to simulate naturalness and to control the ripening of packaged fruit.

Criticisms of the concept of food regimes stress its lack of explanatory content, omission of human agency, over-reliance on the experiences of the developed world, neglect of national regulatory processes, and high level of abstraction (Bernstein, 2016; Marsden et al., 2016; Pritchard et al., 2016). Nevertheless, it highlights emerging divergent trends within contemporary world agriculture as globalization and the reliance on industrial-style methods meets resistance from consumer-led movements that favour organic production and foods with fresh, local, and sustainable connotations (Pretty, 2002).

Alongside the debate about food regimes, agricultural geographers have produced another view of episodic change applying to the agrifood system, in terms of hypothesizing an approximate parallel of the change from Fordism (mass production and consumption characteristic of highly developed economies during the 1940s-1960s which extended Henry Ford's automotive factories and production-line work) to post-Fordism (new information technologies and the growing importance of the service sector and white-collar work) (Amin, 1995; Jessop, 2006). Partly encompassing the shift from the second food regime to the third, it takes the form of a move from productivism to postproductivism, involving transitions from different work and production practices, different relations of production, and changes in the regulations governing production (Tilzey \& Potter, 2008).

\subsection{Productivism}

Productivism is essentially typified by commercial farming worldwide post-1945 in which technological advances, often encouraged by the state through research and advisory services, have enabled major advances in productivity (Bowers, 1985; Friedma \& McMichael, 1989). The Common Agricultural Policy (CAP) of the European Union (EU) is one of the best examples of this state support aimed at maintaining a viable farm population and increasing output. However, unintended consequences have included a substantial restructuring of production with fewer individual enterprises, growing farm indebtedness, negative environmental consequences and wide variability between individual farms and regions (Marsden, 2011). The geographical component of agricultural development under the CAP is often simplified into a duality between small, often marginal, family farms and larger heavily capitalized farm enterprises with links to agribusiness. The latter tend to be concentrated in the areas with the most favourable physical conditions for farming whilst the latter dominate in upland and mountainous areas (Hill, 2012), providing scope for investigation of the widespread retreat of agriculture from such areas in the Mediterranean and Atlantic fringes (Juan and Díaz, 2016; Lasanta-Martínez et al., 2005; Melendez-Pastor, 2014; Rescia et al., 2008) while intensifaction occurs in irrigated areas (Serra et al., 2014). 
The CAP has attempted to create a favourable economic environment for farming, through specific financial supports and inducements for farmers, often directly dictating farmer behaviour, e.g., via use of production quotas. It is the spatial consequences of these measures, and especially the various reforms undertaken, starting with the so-called MacSharray reforms of 1992, that have proved fertile grounds for geographical investigation (Bolsius, 1993; Serrano, 2017). Similarly, the expansion of the EU has offered new opportunities for geographical research, notably on land reforms enacted in central and eastern Europe, which have fostered agricultural modernization (Hartvigsen, 2014). Other research has examined changes to farmer-state relations, through the lens of macro-policy changes associated with world trade negotiations and creation of the World Trade Organization (Margulis, 2014).

\subsection{Post-productivism}

The term 'post-productivism' first appeared in the literature in the early 1990s when it was used to refer to certain responses to perceived negative outcomes from productivism. As conceptualized by Bowler (1992), this meant a reversal of tendencies towards intensification, concentration and specialization of production, with diametrically opposing moves to extensification, deconcentration and diversification (or pluriactivity). Post-productivism was described as involving a shift from quantity to quality in food production; the growth of alternative farm enterprises and networks (AFNs) as part of pluriactivity on farms (Goodman, 2004); state efforts to encourage a return to more traditional, sustainable farming systems through agri-environmental policies; the growing environmental regulation of agriculture; and the progressive withdrawal of government support for agricultural production (Barnes et al., 2016; Halpin, 2017).

There has been much research on AFNs (e.g. Bruckner, 2018; Thorsøe \& Kjeldsen, 2016), which at a local scale may be most readily developed through new linkages between farms in the peri-urban fringes of major cities and the consumers of their produce. Yet, agriculture in these fringes often struggles to survive in the face of urban pressures and sprawl, which undermine viable agricultural production in the 'city's countryside'. So, there are tensions between urban expansion and maintaining viable agriculture in the fringe. AFNs offer one avenue of survival for farmers there, linked to growing public concerns regarding the types of food that they eat, its origins and how it is transferred from farmers to consumers. Geographers have used the term 'reconnection' to symbolise how many AFNs are renewing links between producer and consumer that may have been lost through mass production, industrialised agriculture and the growing dominance of supermarkets (Kneafsey et al., 2017; Lamine \& Dawson, 2018).

Reconnection is part of an increasingly complex range of consumer demands involving segmentation of the food market, within which some groups are seeking out sustainably produced food that is 'natural' and locally produced. This is the antithesis of 'fast food' consumption and includes various 
short supply chains such as food purchases in farmers' markets, pick-your-own schemes, farm shops, vegebox schemes and other direct marketing arrangements (Allen et al., 2003). In the developed world, the northern European and North American countries have seen the largest growth in direct marketing, partly because there has been a stronger tradition maintained in southern Europe with respect to "a culinary gastronomic tradition based on local products" (Paül \& McKenzie, 2013, pp. 96-97).

Another aspect of post-productivism is the loss of agriculture's central position in wider society, as fewer and fewer people work in the industry. This has been accompanied by changing public attitudes towards agriculture, often unfavourable when the media has portrayed farmers as being responsible for practices harmful to the environment and rural landscape (Woods, 2005). However, one response to these negative consequences of modern farming activities has been the introduction of agri-environmental policy measures aimed at promoting environment-friendly actions, often accompanied by stronger pollution regulations and the dismantling of protectionist state policies. These measures have also been part of the commodification of former agricultural resources, namely land, wildlife habitats, and farm buildings.

Post-productionism has been associated with new opportunities for farmers as presented in new regulations supporting rural development and new forms of agricultural production. In the EU this has included attempts to promote production of 'quality' foods, including organically and locallyproduced foods (Balogh et al., 2016), through new regulations, e.g., protected designations of origin (PDOs) and patented geographical indicators (PGIs). PDOs and PGIs have formalised linkages between particular foods, notably cheese and drink products, to specific places and regions, e.g., champagne, Stilton cheese, cognac, Roquefort and Parma ham (Esteban Rodriguez, 2017; Kizos et al., 2017). These are specialty food products (SFPs) associated with authenticity of geographical origin and traceability. They represent a 'relocalization' of the agri-food system in which the products command a market benefit if they are effectively marketed (Goodman et al., 2012). The estimated worldwide sales value of products protected by geographical indications in the EU in 2010 was $€ 54.3$ billion (European IRP Help Desk, 2016, p. 5). The potential benefits of PGls and other quality registration schemes are increasingly being recognized with respect to development and promotion of regional economies, in both national and international markets (Van Caenegem \& Cleary 2017).

Geographers have contributed new theory to help understand post-productivism, identifying new regulatory conditions and links to other 'transitions,' and have tested the extent to which postulated changes have occurred (Wilson, 2001; Mather et al., 2006). Yet, despite some evidence of postproductivism, most farmers have remained firmly productivist and many general agricultural policy adjustments in the developed world have focused on increasing competitiveness and the need to produce food for mass consumption (Walford, 2003). This means that agricultural production is 
linked inherently to globalizing processes, impacting differentially in space and time. In some cases, especially in North America, changes are promoting greater development of industrial practices and more mass consumption, not less. This has given rise to the term neo-productivism (Wilson \& Burton, 2015). Friedland (1996) gives a good example of this, with reference to the growth of 'annualization' of production, referring to year-round availability of temperate fruit and vegetables in markets worldwide, with imports enabling strawberries from California, Spain and Israel to supply Europe throughout the winter period. However, a new conceptualization for recent changes to farms and the wider countryside has been formulated, supplanting the focus on post-productivism, termed 'multifunctionality'.

\section{Multifunctional agriculture}

\subsection{Theorizing multifunctionality}

In the last decade an alternative conceptualization to the move from productivsm to post-productivism has been proposed, namely multifunctionality. This refers to the multiplicity of roles played by agriculture; that is as well as possessing a primary food-producing role, it also performs additional economic, environmental, and socio-cultural functions in rural areas (Almstedt et al., 2014; Wilson, $2007,2008)$. Hence the term is used to recognize that agricultural systems include non-commodity values as well as commodity and food values. It acknowledges that agriculture has multiple functions and outcomes, which should all be recognized and valued because they often benefit society, e.g., by contributing to the ecology, landscape, and rural society. Farming not only produces food and fibre, but it also contributes desirable environmental and ecological outcomes and other products that traditionally have not carried a recognized monetary value, e.g., rural society and its values, rights of way, and landscape. These varied roles are increasingly acknowledged by policy makers, and they contribute to the generation and management of rural landscapes and ecological features, and supporting rural population, especially in marginal and/or peripheral areas.

Policy reforms to the EU's CAP have accommodated this multifunctional role of agriculture, which has contributed to one understanding of multifunctionality as essentially a policy-led process describing current agricultural trends, e.g. the EU's role in urging the maintenance of farm subsidies in the World Trade Organization's Millennium Round, and the attempt to both decouple support from production and recouple it to agri-environmental and rural development concerns (Bieling and Pleininger, 2017). There are other supports for multi-functionality within the EU, such as its LEADER program, which aims to reconfigure local resources, redefining the social role of agriculture, and increasing the value added to farm products (Kull, 2014). Other elements supporting multifunctionality include a range of agri-environmental policies, and rural development regulations that emphasize farm diversification, rural tourism and landscape conservation. However, there is ongoing debate that addresses the notion of agricultural multifunctionality with respect to previous 
ideas about the productivist-post-productivist transition. The debate tends to conceive of multifunctionality in broad holistic terms with various economic, cultural and policy-based elements (Holmes, 2006; Wilson, 2010).

Wilson (2007) viewed multifunctional agriculture in terms of a transition from a dominant concern with the production of food and fibre towards a new 'regime' that embraces broader interests, such as the production of nature and spaces for leisure. Hence, whilst some farmers are still fully engaged in producing traditional farm outputs, such as grain and meat, many may also be viewed as environmental managers or as the providers of tourist attractions or contributors to rural manufacturing and service activities, i.e. multifunctional products and spaces. This transition goes well beyond traditional conceptions of agriculture, but it can be placed in the context of a move from productivism to post-productivism. He recognizes different strengths of multifunctionality: from weak to strong across a normative spectrum of decision making bounded by productivist (weak) and nonproductivist (strong) multifunctional action and thought (Wilson, 2009). Hence, farm development pathways through time can be traced in terms of moves from weak to strong and vice-versa. Yet, he also argues that a simple linear conceptualization is too simplistic and that instead "we should conceive of multifunctionality as a spatially complex nested hierarchy comprising different interlinked 'layers' of multifunctional decision-making ranging from the farm level to the national and global levels" (p. 269). The farm level is where there is multifunctional action 'on the ground', but its effects can be translated at different scales, especially in a rural community or at a regional level, e.g. through impacts on employment and income generation. Policies introduced at different levels (international, national, regional, local) can impact on individual farms and so affect which path the farmer decides to take. Responses to dominant economic imperatives are likely to produce weak multifunctionality, in which farms focus exclusively on producing crops and livestock (superproductivism or neo-productivism), whereas a 'super'-environmental response might lead to land being taken out production (non-productivism). Wilson (2010) also argues that at the intersection of economic, environmental and social considerations strong multifunctionaility is generated and it is this that can produce resilient rural communities (see also Robinson and Carson, 2016).

\subsection{Environmental and ethical multifunctionality}

While labels such as 'weak' and 'strong' can signify the extent to which farms may have diverged from a sole concern with producing food and fibre, that production may still be performed under a variety of different scenarios, some highly productivist but others considering other concerns such as delivering environmental and social benefits from production. So, one route towards delivery of multifunctionality has been through agri-environmental policies, that explicitly require farms to be 'environmentally friendly'. Often these have been situated within the realms of ameliorating some of the worst negative environmental externalities from productivist agriculture, but others have fostered moves towards forms of landscape stewardship in which positive environmental outcomes assume 
much greater prominence in farm decision making. Hence, multifiunctionality can also be linked to notions of sustainability in that a fundamental idea within the latter is to combine economic and social endeavours towards generating conservation functions of ecological systems (Helming \& Wiggering, 2003).

Agri-environmental schemes (AES) are mechanisms whereby landowners and other individuals and bodies who are responsible for land management can be incentivized to manage their land in an 'environmentally-friendly' fashion. Many schemes were pioneered in the EU, which between 20072013 spent $€ 23$ billion on AES, applied to 46.9 million ha as part of the CAP. For 2014-2020 EU spending on AES will rise to $€ 25$ billion, increasing from $25 \%$ of total spend in the previous period to $30 \%$ (European Commission, 2015). The increase reflects adoption of a wider range of objectives, such as climate change mitigation, promotion of organic farming and so called 'climate and environment investment' measures. In addressing these objectives, participatory techniques have been developed by agricultural geographers to help integrate multiple objectives into landscape planning, including collective visioning for the future, mapping of local stakeholder values to inform priorities for conservation, and segmenting land managers according to different types of values and farming motivations to improve targeting of policy (Forrester et al., 2015).

All AES schemes targeted at farmers are intended to promote better stewardship of the land, recognising that farming involves production of landscape, often with positive agri-ecological dimensions, as well as production of food and fibre. However, research by Raymond et al. (2016a) illustrates that among farming communities there is diversity of understandings of the term 'stewardship', with four different interpretations recognized (Raymond et al., 2016b):

- environmental: managing environmental features so they are protected for future generations, which often involves implementing measures to encourage wildlife;

- production: maintaining productivity of land for future generations, possibly by using traditional farming techniques, but not possessing the same conservation goals as for the environmental category;

- holistic: recognizing interactions and interdependencies between production and the agriecological system; this may entail maintaining or enhancing landscape diversity through a mosaic of different land uses, including field boundaries, such as hedgerows; and

- instrumental: defining stewardship in the context of government policy or an incentive; so, stewardship means acting in accordance with a given scheme whereby land managers are paid for pro-environmental actions.

In a study of forty farmers in south-west England by Raymond et al. (2016a), the sample was almost evenly split between the first, third and fourth of these categories, but with a smaller proportion from 
the production category. The views presented by the farmers about future agri-environment policy highlighted some of the tensions present within the wider farming community. Production respondents felt that AES neglect the prime need to encourage food production whereas environmental and holistic farmers felt AES did not support development of a local 'green' food culture and its associated social infrastructure.

Although a component of policy in the EU since 1986 and the creation of Environmentally Sensitive Areas (Robinson, 1994), AES and their associated payments for environmental/ ecological services (PES) have a longer history in North America where probably the world's largest and longest running PES program is the Conservation Reserve Program in the United States, operating in various forms since the 1930s (Hellerstein, 2017). This pays around $\$ 1.8$ billion p.a. through 766,000 contracts with farmers and landowners who place a total of $140,000 \mathrm{~km}^{2}$ of what are defined as 'environmentally-sensitive lands' into the Program. The farmers agree to plant "long-term, resourceconserving covers to improve water quality, control soil erosion and enhance habitats for waterfowl and wildlife" (FSA, 2018).

A more recent scheme, also on a vast scale, is the much-vaunted Chinese PES scheme, the $\$ 43$ billion Grain for Green program, also known as the Conversion of Cropland to Forest and Grassland Program or the Sloping Land Conversion Program, established in 1999, which has removed marginal land from agricultural production to deliver ecological gains (Wang et al., 2017). The program is China's largest ecological restoration program and rewards farmers for not clearing forested slopes for farming, thereby reducing erosion and cutting the flow of sediments from farmland into rivers. Satellite remote sensing has revealed that across China's Loess Plateau, Grain for Green has increased tree cover by about $41 \%$, with significant increases in enhanced vegetation index (EVI), leaf area index, and the fraction of photosynthetically active radiation absorbed by canopies (Xiao, 2014). By the end of 2012, Grain for Green had converted 9.1 million ha of cropland to forest and 0.64 million ha to grassland (Song et al., 2014).

In the EU AES have included various intensity reduction measures, notably management of lowintensity pasture systems, integrated farm management, promotion of organic farming, conservation of high-value habitats and conservation of target flagship species. There have been numerous different schemes, usually voluntary in terms of farmer participation, with varying aims and different levels of support, but many of which have attracted researchers' attention in terms of trying to understand farmer motivations. In general, participation has been encouraged by financial incentives, especially promoting greater security of income, a commitment to the scheme's environmental conservation aims, the fit with farm-management plans and lack of alteration required to existing management arrangements (Lastra-Bravo et al., 2015; Riley, 2016). Typologies of farmers have been formulated based on the characteristics of participants and non-participants or on adopted pro-environmental behaviours (Burton, 2014; McGuire et al., 2015; Riley, 2011). 
Most of the measures contained with AES are geared towards obtaining a better balance between agriculture's impact on the environment and the demand for food by the world's population. In the main, they have not been concerned with attainment of any specified sustainability targets, though promotion of organic farming has been an option in several programs. This has been one way in which farmers have been encouraged to move away from the industrial, productivist model of farming as part of what has been termed the naturalization food and agricultural (NFA) paradigm (Rausser et al., 2015). The paradigm subsumes diverse arguments relating to food safety, obesity, the role of agriculture in climate change, the demise of family farming, and the concentration of agribusiness. It is a paradigm that has grown in popularity, especially in the West, through growing interest in organic and environmentally-friendly farming and concerns over negative externalities from industrialized agriculture. It has exerted growing political influence, despite champions of alternatives to the industrial system often struggling to produce economically rational policy proscriptions. In part, this is because the paradigm includes several different socio-economic and biophysical conditions and attendant diverse potential 'solutions', which themselves are often problematic. For example, wholesale moves from an industrial model to farming systems favoured by NFA could seriously compromise food security (Leifield, 2016). As shown by numerous studies (e.g. Servon \& Pink, 2015; Oostindie et al., 2016), the reality is that there is increasing co-existence of both globalized and local systems of production, serving different markets. This implies that policies which are applied on a 'one size fits all' across every producer may need to be recast. There is a need for more analysis of alternative environmental and resource policies that consider the effects of agriindustrial concentration, food safety and food security, especially by reformulating welfare and political-economic arguments (Anderson at al., 2014; Rausser \& Farrell, 2016).

Meanwhile, geographers have made substantial contributions to debates about the spread of organic agriculture, determining just what is meant by sustainable agriculture and the growth of alternative food networks (AFNs) (Robinson, 2009). As discussed with respect to developed countries in section 2.3, the latter are related to challenges or constraints on globalization posed by growing concerns over ethical aspects of production and trade. This also includes issues relating to the treatment of workers and producers within farming systems in developing countries. The concerns have been translated into various forms of action, one of which is creation of the FairTrade kite-mark, now recognized worldwide as an indicator of the ethical trading of products, which aims to ensure that producers receive a fair price for goods supplied. This has been applied primarily to tropical cash crop products, such as tea, coffee and bananas (Lekakis, 2013). Ethical trade has also included fair-trade agreements, safe working conditions for farm workers, and sustainable and environmentally safe natural resource management. References have been made to ethical consumerism (e.g. Burke et al., 2014; Harrison et al., 2005) as representing the 'fourth wave' of consumption. This reaffirms a moral dimension to consumer choice (Gabriel \& Lang, 2015) and is 
linked to a growing debate about the morals and ethics of global trade (Dunning, 2004). For example, "the improvement in trading relationships through ethical trading, enforced by organic concepts of production, contributes to the accumulation of both natural and social capital, through greater sustainability of natural resources and increased access by producer groups to networks of production and trade" (Browne et al., 2000, p.70).

New networks have been created that address concerns for rural social justice, promoting the rights of people to healthy and culturally appropriate food produced through sustainable methods and the right to define their own food and agriculture systems (Robinson, 2018b). These emphasize a need for more returns to accrue to the producers of crops and livestock, and so are allied to the fair-trade social movement (Jaffee, 2014). The latter has been a potential alternative to the injustice and inequality of the global market system, originally developed through rural co-operatives to empower small farming communities. Frequently, market-based approaches have been adopted, with fair-trade produce forming a niche market or an alternative to established supply chains (Wilson, 2010), which is described by Anderson (2015) as a new international "moral economy". This has been driven in part by consumers as a lifestyle choice, but greatly influenced by international development campaigns featuring non-governmental organizations (NGOs) and alternative trade organizations who have affected global supply chains.

'Alternative' networks have emphasized partnership, alliance, responsibility and fairness, whereby producers should receive a guaranteed minimum premium price with the proviso that they meet specified quality standards and marketing deadlines (Lockie, 2008). NGOs like Oxfam have been vital to these networks, encouraging new trading companies, such as Cafédirect, which have in turn become a crucial link between local tropical producers and their consumers in the developed world. Increasing numbers of consumers have been prepared to pay a higher price for a fair-trade product like Cafédirect's ground and freeze-dried coffee as opposed to a conventionally marketed product.

\subsection{Ecosystem services}

The various aspects of multifunctionality discussed above have given rise to attempts to measure the changes occurring, in part to quantify impacts (e.g. Sal \& García, 2007). One aspect of measurement that has become a major focus of study has been the assessment of ecosystem services (ESS). This refers to attempts at measuring the transformations in agricultural systems worldwide that have had such major impacts on agri-ecological systems, often dramatically altering the ESS they generate. ESS refer to the benefits derived by people from both natural and managed ecosystems, "whereby the ecosystem directly or indirectly provides production, necessities and services, including clean air, water, food and fuel" (Song et al., 2017, p. 114). Payments for ecosystem services (PES), often inherent to government-funded agri-environmernt schemes, are 
incentives offered to farmers or landowners in exchange for managing their land to provide some sort of ecological and environmental benefit.

Four types of service derived from agri-ecosystems are usually recognized (Porter et al., 2009; Su et al., 2012):

- provisioning, such as the production of food and water;

- regulating, such as the control of climate and disease;

- supporting, such as nutrient cycles and crop pollination; and

- cultural, such as spiritual and recreational benefits.

Within the four broad categories, 24 separate services were identified and assessed by the Millennium Ecosystem Assessment, a United Nations-sponsored report published in 2005, designed to assess the state of the world's ecosystems. Changes to ESS have attracted much attention in human geography, ecological economics and related disciplines (Baral et al., 2014; Long et al., 2014), including a growing volume of research that assesses how changes to farming (agriecological) systems are affecting the different types of service (in effect measuring different aspects of multifunctionality).

Traditional farming systems, which combine crop and livestock production to promote soil fertility, comprise many positive ESS, e.g. through soil and water conservation measures. The provisioning function for grain crops in these systems is balanced with inputs from animal manures (Wood et al., 2015). In such systems agriculture contributes to healthy agri-ecosystems and overall biodiversity conservation, albeit with less diversity than in climax vegetation systems (Simoncini, 2009). Modern farming methods can contribute greatly to increases in provisioning services, but they also generate ecosystem disservices, such as those associated with pollution of land and air and loss of biodiversity (Shi et al., 2014).

There has been much focus on changing ESS in China where the enormous scale and scope of the agricultural and economic transformations following major economic reforms in 1978 have delivered some of the greatest changes to ESS worldwide, incorporating substantial modifications to land use and land cover (Tang et al., 2013; Zhao, 2013). Biodiversity and ecosystem productivity have been profoundly affected, modifying the structure of ecosystems, and thereby affecting ESS both positively and negatively (Liu et al., 2015). Urbanization has brought dramatic losses of farmland, introduction of intensive farming systems and concomitant land use modifications that have produced many changes to ESS (Deng et al., 2015). Several native species have been endangered and important functions of ESS have been reduced, including pest control and pollination (Wang and Zhou, 2014). Reduced biodiversity, soil degradation, and water pollution are major negative consequences (Zhu et al., 2010). 
Attempts to restrict negative consequences for ESS have featured in major Chinese policy initiatives, also attracting much analysis by geographers (DeFries et al., 2007). Policies include measures to address the loss of agricultural land to urban development, as part of concerns to protect national food security. One aim is to create a national base-line of 120 million ha of farmland, with local authorities responsible for controlling urban sprawl (Jiang et al., 2016; Peng et al., 2017). However, as these authorities earn income from land sales to developers, rapid losses of farmland still occur, often only balanced by converting marginal lands to agriculture that may be ecologically fragile and unsuited to modern farming methods. In contrast, pro-environmental policies, such as Grain for Green, have had the opposite effect: removing marginal agricultural land from production (Chen et al., 2016). Agricultural and rural geographers in China are playing a major role not only in analysing these various changes to ESS but also in developing practical solutions to meet the demands of feeding the huge population while at the same time addressing problems of what has been described as the 'rural disease', that is rural poverty, depopulated 'hollowed' villages, land abandonment and diminished capacity to maintain output in some areas (Liu et al., 2014, 2017; Liu, 2018; Liu \& Li, 2017).

Research on the agri-ecological dimensions is just one aspect of a growing wealth of multidisciplinary studies on ESS. For geographers the attraction is that it is a concept linking environmental, social and economic systems, in which services 'cascade' to deliver goods and benefits in a linked system from a biophysical system or process to functions to services delivering benefits that have measurable benefits (Potschin \& Haines-Young, 2016).

\section{Topical concerns in agricultural geography}

Of necessity, given space constraints, the preceeding broad overview of agricultural geography's conceptualization of the long-term transformations to the agri-food system has portrayed a concern largely with the developed world, especially using examples from Europe. There has been some acknowledgement of the major contribution being made by Chinese researchers in the last two decades, but little formal discussion of the work of agricultural geographers in addressing problems that are manifest at a global scale or specifically relate to agri-food systems in the developing world. This section seeks to redress this balance by focusing briefly on three recent closely-related concerns that are at the forefront of current agricultural geography research, and hence the use of the word 'frontiers' in the paper's title.

\subsection{Food security}

An increasingly important aspect of agricultural geography in recent years has been a focus on issues related to food security. This reflects growing worldwide concerns about not only food security at a national level but also access to food for certain sections of society. Traditionally the 
latter has referred to the large proportion of people in developing countries living on the edge of starvation, but there are emerging concerns relating to new food-related issues in the developed world. The latter include so-called 'food poverty' (in which the poorest in wealthy countries have much more limited diets and access to food than the majority) (O'Connor et al., 2016), overconsumption leading to a huge increase in the proportion of the population suffering from obesity (Pearce \& Whitten, 2016), and the need to plan for national food deficits in the face of climate change, economic shocks and other hazards (Clapp, 2017). Current threats to global food security have been described as "the perfect storm" by Sir John Beddington, former UK Government Chief Scientific Adviser, referring to the impacts of the continued growth of population, affluence, and ecological damage worldwide (Cairns \& Krzywoszynska, 2016).

Although a steadily falling proportion of the world's population dies each year from malnutrition or lives on the edge of starvation, there remain problems in ensuring that people in developing countries have access to safe and nutritious food. There is a complex set of linkages between key factors of availability, access, utilization and stability, which have formed the backdrop to geographical research investigating this problem and broader issues of food security. Research has included the impacts of the adoption of Western-style diets in the developing world (Raphaely \& Marinova, 2015; Yuan et al., 2018), stresses to the physical base worldwide resulting in declining crop yields in some countries (Tilman et al., 2017), the deleterious impacts of conflict and natural hazards (Blaikie et al., 2014), gender imbalances in access to resources (Eastin, 2018; Shortall, 2015), severe localized micronutrient deficiencies (Clark \& Hobbs, 2015), and the potential for major negative consequences from climate change (Castree, 2015; Wiebe et al., 2015).

In the past, geographers' contributions to studies of hunger and malnutrition focused on technology transfers from the rich global North to the poor South, as symbolized in the package known as the "Green Revolution," popularized in the 1960s, comprising a series of adoptions of key innovations, with various phases, and providing wide scope for research on its diffusion, impacts, economic outcomes, and contribution to alleviation of world hunger (Basu \& Scholten, 2013). The most recent phase of the Revolution, commencing in the early 1980s, refers to a move beyond development of high-yield crop varieties to genetic modification (GM). New methods to control pests helped produce a gene revolution and, subsequently, a variant widely adopted in North America, GM and biotechnology (Altman \& Hasegawa, 2017).

GM involves the insertion of genes with known characteristics and/or products into a strain of plant previously lacking a desired trait. This may produce quicker and more precise outcomes when compared with traditional methods of plant breeding, and thereby increase the efficiency of plant genetic improvement. There has been a focus on breeding specific desired traits, such as tolerance for herbicides, longer shelf-life, saline tolerance, removal of characteristics deemed undesirable, and creation of more palatable, nutritious or disease-combative plants. By introducing these 'desirable' 
characteristics, the intention is to improve yields. Yet, there remain challenges that may restrict the further diffusion of GM crops.

The heated debate regarding GM and the production of GM-based foods contrasts different views of the technology. One is that it offers a prospect of massively increased production to dramatically increase the world's supply of certain crops and livestock products, so they can be a major contributor to increasing food security (Dibden et al., 2013); the other view is that they may be harmful to the environment and to human health (Ferry and Gatehouse 2009; Meadows, 2011). This debate has contributed to a slowing of the growth rate of the adoption of GM crops since 2012, partly reflecting impacts of stronger regulation in the agricultural biotechnology industry. In 2016 there were 185 million ha under GM crops worldwide (12\% of global cropland), the principal GM crops being cotton, maize, potatoes, rapeseed, and soybean. Of the global area devoted to these crops, $40 \%$ are in the United States and $23 \%$ in Brazil. Over half of all GM crops have been engineered for herbicide tolerance, offering easier control of weeds, less tillage, and reductions in soil erosion, rather than for any intrinsic improvement in food quality or pest resistance (ISAAA, 2016).

Much of the production of GM crops has been by farmers who can afford its inputs, notably annual purchases of seeds. The principal developers of the technology have been companies manufacturing their own brand of herbicide, creating GM crops capable of resistance to that brand. Hence, it has been large US-based corporations like Monsanto, Dow, Du Pont, Hoescht and Calgene who have pioneered its development. The former has developed glyphosphate herbicides like Roundup. Its herbicide-tolerant GM plant varieties can be sprayed with Roundup, as in the case of so-called 'Roundup ready' soybeans. Similarly, most of the other GM developers are promoting their own brands. However, in August 2018 in the San Francisco Superior Court of California a successful case against Monsanto, an arm of the German firm Bayer AG, found the company had contributed to cancer in a gardener who used its Roundup herbicide, raising doubts about its future use worldwide.

There have been severe restrictions on the adoption of GM in some countries, notably the UK and Australia. Furthermore, the argument that they represent a solution to problems of food shortage in developing countries has largely been unsubstantiated. Indeed, until 2013 most GM crops were in temperate farming systems rather than being subsistence crops in the tropics. Those available in the latter have been associated with smallholder farmers who then need to buy new GM seed every year rather than following traditional practice and holding back seed from harvest to sow the next year's crop. This adds a deterrent in the form of additional costs.

Some of the problems experienced with the Green Revolution have been repeated with GM, notably that much of the GM-related research and development has failed to address the needs of 
African farmers, ignoring possibilities to develop crops adapted to local environmental conditions (Mclntyre et al., 2009) or to interweave GM crops into the complexity and diversity of agri-food systems (Thompson \& Scoones, 2008). In Africa, it may be non-profit institutions, and not commercially-motivated enterprises, that may introduce the new technology, e.g., Africa Harvest, which has collaborated with the Bill and Melinda Gates Foundation in developing vitamin A-enriched sorghum (Sorghum bicolor) (Thompson, 2016).

\subsection{Land grabs in the 21st century}

One aspect of concerns about food security can be seen in the growth of land grabs. The emotive term 'land grab' was widely applied to the colonial ambitions of the Western powers in the 19th century, especially the so-called 'scramble' for Africa. Its modern usage dates primarily to responses to the world food price crisis of 2007-2008 (Borras et al., 2011), which prompted rising concerns about food security within the developed world. There was a subsequent 'spike' in large-scale agricultural investment in the global South focused on food and biofuel production and, in some cases, access to water resources (Rullia et al., 2013).

Land grabs denote contentious large-scale land acquisitions, generally but not always by non-local transnational companies, financial institutions, governments, and individuals. The acquisitions include the consolidation of foreign-owned plantations in countries that are food insecure as well as so called 'green grabbing' of land and other natural resources for renewable energy (Fairhead et al., 2012). Some of these 'grabs' reflect new forms of capital accumulation in the rural South (Rignall \& Atia, 2017). The finance industry has been a major player behind the purchases, with sovereign wealth funds (SWFs) being prominent. These represent accumulated profits, estimated at over five trillion US dollars, obtained from the sales of oil and other natural resources, which are held by sovereign states. Investment of these funds is designed not only to provide returns on capital but also to address prime concerns of individual states, notably food security issues, especially of concern to oil-rich countries, and for biofuels by other countries (Lawrence et al., 2011). This is a process termed financialization, meaning "the increasing importance of financial markets, financial motives, financial institutions, and financial elites in the operation of the economy and its governing institutions, at both national and international levels" (Epstein, 2002, p. 1). In part it reflects the disproportionate recent growth of the financial sector relative to other sectors of the economy through the impacts of new financial products, new technologies, reduced controls on capital flows, and new opportunities for investment, including into food and farming (Moreira, 2017). However, it should be noted that financialization has been criticized by Christophers (2015) as being too nebulous and lacking explanatory power and conceptual clarity with respect to global change. In response, Lawrence (2015) asserts that it is an evolving concept, which is increasingly being accepted and used, just as other contested ideas such as globalization and neo-liberalism have been. He contends that 
financialization is indispensable to the theorizing of contemporary agrifood restructuring, summarizing its characteristics as follows:

a) the presence of new actors in the financial sector, e.g. the SWFs;

b) the increasingly significant role in the global economy played by financial entities;

c) the plethora of new financial products and instruments affecting the new dynamics of global change; and

d) it is not economically, politically or socially neutral as most power and wealth flowing from investment is appropriated by corporate managers and shareholders so that it rarely 'trickles down' (Vercelli, 2013, p. 42).

The importance of SWFs as a major driver of land grabs increased after the so-called global food crisis of 2007-8. The crisis involved dramatic increases in world food prices, which contributed to political and economic instability (Ghosh, 2010; Swan et al., 2010), following which over US\$100 billion in three years were invested in purchase of farmland by SWFs and private-sector enterprises (Daniel, 2012). Critically, it appears that the new investors are aiming to access some of the world's most fertile agricultural land (Catley et al., 2013), which can supply food to the investor country, as in the case of Chinese investment in beef and cherries in Australia (Magnan, 2015; Robinson \& Song, forthcoming).

A key driver of land grabs has been decreasing per capital availability of farming land worldwide, conversion of farmland to biofuel production, the growing middle class in China and India (producing increased demand for food), the impact of climate change on new opportunities for farm investment, responses to growing concerns over food security, and new speculative opportunities in food and farming (Antonelli et al., 2015; Lazarus, 2014).

Sub-Saharan Africa has been the prime target for direct overseas investments in farmland. Investors have been attracted by much land being deemed to be undervalued or they have used the argument that their investment will bring development to 'backward' rural areas. The reality, though, is that the production associated with this investment is largely destined for the investor countries. This is the case in many recent Chinese projects in both East and West Africa (Cotula, 2013), which has been referred to as a form of neo-colonialism in that the amount of cultivable land available to local farmers is usually reduced. This contributes to reduced food security in the host country whilst enhancing it in the investor country. Research by Sulieman and Ahmed (2017) in East Africa asserts that traditional pastoralism is being threatened by purchases of rangelands, which are being sanctioned by national governments seeking to obtain revenue (see also Schmidt and Pearson, 2016). 
Land grabs encompass a wide variety of land deals, but there are two main categories of land to which they have been applied. First, food and biofuel production has been the concern of politicallydominant classes and corporate interests taking over smallholdings (Hall et al., 2015; Byerlee et al., 2017). This is best exemplified by the advance of sugar cane growing in Brazil for both food and biofuel production (Defante et al., 2018). The second category covers between 450 and 1.7 billion ha worldwide, based on estimates from the World Bank. These are lands assumed to be marginal, underutilized, empty and potentially available for purchase, and which are classified as public lands (Deininger, 2011). They are mainly in Africa and parts of southeast Asia but are mostly productive farmlands managed under various production systems. The variety of different situations represented by these lands gives rise to several different outcomes from land grabs across a spectrum from dispossession of the former tillers of the soil to improved security of tenure for these farmers. However, perhaps the most common outcome is conversion of existing farmland to monocropped plantations, e.g., oil palm, soy and other cash crops. Such conversions are often favoured by local governments because they bring foreign direct investment, including into improved infrastructure, as in the case of Chinese state-owned enterprises (Gu et al., 2016; Lam, 2016). This can diminish local food security and cause disruption if insufficient consideration is given to the livelihoods, rights, and needs of local people, but this is not applicable to every case.

Concerns over land grabs has been subsumed within broader protests about the operation of transnational corporations (TNCs) in developing countries, regarded by some as another form of neo-colonialism, to generate opposition coalitions, some of which now operate worldwide. One is La Vía Campesina (LVC), a coalition of peasant farmers (originating in Mexico), which equates land grabs with the creation of a form of agricultural industrialization and modernization that is forcing subsistence producers off the land. This is often reported as a direct confrontation between the Global South (the losers) and the Global North (the beneficiaries). Hence, LVC has promoted the concept of food sovereignty: "the right of peoples to healthy and culturally appropriate food produced through sustainable methods and their right to define their own food and agriculture systems" (US Food Sovereignty Alliance, 2018). It has publicized the need for national sovereignty over market-based food exporting (Rosset, 2013). Primarily, LVC has "politicized issues of natural resource access and control, placing rural producers, labourers, and indigenous groups at the forefront of resistance to climate change reformism and corporate concentration in agriculture and food" (Rignall \& Atia, 2017, p. 7).

The ideas of LVC challenge the profit motive for food production in favour of a focus on the needs, interests and rights to self-determination of farmers and farm labourers. There are several aspects to this challenge, including objections to the undermining of food sovereignty by intellectual property rights, which, for example, may restrict farmers from saving and reusing seeds in future seasons or from using them for research (Robinson, 2010). LVC maintains a worldwide campaign against the 
further control of seeds by TNCs and in favour of agri-ecological innovation (Scoones et al., 2015). It has also highlighted potential human rights violations associated with land grabs that displace locals (White et al., 2012) while emphasizing the need for greater justice for women and indigenous groups working in agriculture (Deere and Leon, 2001). Many of the concerns of LVC challenge the control over food production exerted by big corporations, as it focuses on local and regional environmentally-friendly agriculture (Alkon, 2013). LVC promotes smallholdings and creation of strong, viable, local markets.

Edelman (2014) argues that contributions by geographers and others to debates about food sovereignty are just starting to address key polemic issues such as the role of long-distance trade, the implementation of relevant legal norms, and whether 'agri-ecological' production can feed a growing global population. He highlights the work of Jarosz (2014) who links discourses about food security and food sovereignty, noting that 'food security' "is typically associated with technocratic, productivist approaches to development that emphasize quantitative measures of sufficiency, whether for individuals, households, or nations" (p.169-170). In contrast, food sovereignty is often expressed as part of a critique of corporate industrial agriculture and the latter's negative impacts on small farmers, society and the environment, plus argumenrs in favour of biodiverse agri-ecological production.

One response to the problem of how to ensure food security has been to propose the need for sustainable intensification (SI), which aims at increasing the intensity of inputs to the agri-food system (to increase output), but without compromising the sustainability or ecological integrity of food production (Garnett et al., 2013, p. 33). Examples of increased yield derived from the development of new crop varieties are usually regarded as an essential component of SI. Yet, there are diverse views about what should be regarded as 'sustainable' and 'intensification' in the broad context of the agri-food system. Indeed, some have argued that it is too narrowly focused on production, or that is simply a contradiction in terms (Petersen and Snapp, 2015). The economic interpretations of SI stress changes involving increased production capacity, rising consumption of goods and services, and generally improved human wellbeing. These are all viewed as depending on policies encouraging investment in the capital base (e.g., education) and supporting technological changes to increase productivity while reducing use of natural resources and lessening the ecological impacts of consumption (McMichael, 2014).

In Sl, intensification is associated with increased yield or outputs per unit area/input, diversification (e.g., widening the choice of feeds and forage), integration of crops and livestock, and improved resilience to market shocks and risks from climate change (and hence the term climate-smart agriculture) (Campbell et al., 2014). Increased intensity can possibly involve using previously uncultivated land; more labour, machinery and other inputs; as well as new varieties and innovations. However, some of these aspects may be damaging to ecosystems. Ecologically-based 
views of SI emphasize the need to support the physical and biological systems that underpin agrifood systems. In this context desirable policies are those designed to maintain resilience in face of unpredictable but inevitable shocks to human and ecological systems. The need to minimize negative environmental outcomes from intensification of agriculture has been referred to as ecological intensification (Tittonell, 2014).

To date research on SI has come primarily from agricultural economists and policy analysts, but geographers are beginning to investigate farmers' responses to new policies linked to $\mathrm{SI}$, and the new patterns of production and consumption occurring within the broader context of food security (Fish et al., 2014).

\subsection{Agriculture and climate change}

One of the chief threats to food security worldwide comes from climate change, with the potential impacts of climate change upon agriculture featuring in important work by geographers for at least the last three decades. Many of the initial geographical studies concerned inputs from physical geographers and specialists in remote sensing and geographical information sciences (GIS) who modelled potential characteristics of future climates (Watts et al., 2015). This global circulation modelling suggests that climate change is likely to have significant negative effects upon agriculture worldwide, with severe impacts in lower latitudes. Some argue that negative effects can already be observed, with global yields of wheat and maize reduced by $5.5 \%$ and $3.8 \%$ respectively since 1980 (Campbell et al., 2014, p. 40). As well as being adversely affected by climate change, agriculture is a major contributor to the production of GHGs: not only accounting for between 19\% and $29 \%$ of total emissions directly (i.e. $\mathrm{N}_{2} \mathrm{O}$ and $\mathrm{CH}_{4}$ ) and indirectly from land cover change driven by agriculture $\left(\mathrm{CO}_{2}\right)$ but also increasing at 1\% per annum (Lamb et al., 2016).

Increasingly, human geographers have made a growing contribution to studies about the impact of climate change on agriculture, involving examinations of likely regional and local effects on food security, with concomitant needs for mitigation and adaptation measures (Eriksen et al., 2015; Kabisch et al., 2016). Without the latter, it is South Asia and sub-Saharan Africa that are deemed most likely to suffer negative impacts on the staple crops which are currently important to large numbers of food insecure human populations. Areas most reliant on rain-fed crop production may be most severely affected. Mitigation is possible but will incur costs not always readily born in poor countries. It already involves adoption of conservation measures (e.g., planting drought- and/or heat-resistant crop varieties), enhancing forest cover (as in the widely adopted Reduced Emission from Deforestation and forest Degradation programs, REDD), replenishing groundwater, and using renewable energy.

REDD involves incentivizing changes to the way forest resources are used, often aimed at reducing $\mathrm{CO}_{2}$ emissions by preventing further loss or degradation of tropical forests. This includes direct 
payments to producers or carbon trading schemes, in which industrialized countries offset their own emissions by transferring funds as carbon credits to developing countries. This was recognized in the 1997 Kyoto Protocol, an international treaty linked to the United Nations Framework Convention on Climate Change, which commits its signatories to set internationally binding greenhouse gas (GHG) emission reduction targets. An addition to the original aims of REDD, and hence the term REDD+, is the role of conservation, sustainable management of forests and enhancement of forest carbon stocks in developing countries, which was recognized in the 2007 Bali Action Plan.

Given that deforestation and forest degradation is the second leading cause of global warming, responsible for about 15\% of global GHG emissions, REDD and REDD+ have the potential to make serious inroads to this problem (Guadaloupe et al., 2018). Yet, there have been concerns raised about the effectiveness of REDD+, especially its impacts on small farmers, as major effects in terms of reduced forest loss are hard to document (Fletcher et al., 2016). Angelsen et al. (2017) give four reasons for this:

- REDD+ has not yet been implemented at the scale needed to make a difference;

- REDD+ has evolved from an initial vision involving PES into a modified version of previous and largely ineffective conservation efforts;

- REDD+ has been blocked by powerful actors interested in maintaining the status quo; and

- REDD+ is conceptually flawed in its design as a PES and market-based instruments scheme.

REDD+ was also premised as being integral to a global cap-and-trade carbon market, but that has not materialized, with the 2016 Paris Agreement within the United Nations Framework Convention on Climate Change, which dealt with GHG-emissions mitigation, adaptation, and finance (to commence in 2020), failing to create the binding national caps needed.

Broader concerns related to climate change include research on related environmental justice issues, highlighting food security where rural people especially rely on weak or non-existent food markets (Arce \& Marsden, 2008; Heasman \& Lang, 2015). Effective adaptive planning may be limited because of inadequate knowledge of the nature of regional and local climate changes, though appropriate policy principles have been proposed. Some of these are embodied in climate-smart agriculture (CSA).

CSA is an approach to agricultural development in which farming systems are transformed and reoriented to support food security under the new physical conditions created by climate change. It acknowledges that widespread changes in rainfall and temperature patterns because of climate change are threatening agricultural production and increasing the vulnerability of people who depend on agriculture for their livelihoods, which especially includes producers and farm labourers in developing countries. It is argued that climate change will disrupt food markets and create major 
problems for maintaining food supplies. However, this can be tackled by raising the adaptive capacity of farmers whilst increasing resilience and resource use efficiency in agricultural production systems (Lipper et al., 2014). CSA aims to co-ordinate actions by all those involved in agricultural production, including researchers, civil society and policy makers to develop 'climate-resilient pathways' based on four main sets of actions:

(1) increasing knowledge about links between climate change and agriculture;

(2) increasing local institutional effectiveness;

(3) encouraging stronger inter-relationships and integration between policies for climate change and agriculture; and

(4) linking climate and agricultural financing.

A prime component of CSA is identifying potential synergies and trade-offs between these objectives. It is argued that CSA deviates from previous approaches to food security by "emphasizing the capacity to implement flexible, context-specific solutions, supported by innovative policy and financing actions" (Lipper et al., 2014, p. 1068).

Campbell et al. (2014) argue that CSA is closely linked to sustainable intensification as the latter can reduce emissions of GHG per unit of output, through lower direct emissions and fewer changes in land cover. CSA integrates climate change into the planning and implementation of sustainable agriculture and informs priority setting. The essence of CSA is a focus on building adaptive capacity in agriculture, but this represents a wide diversity of approaches. A commonality is to build resilience through better management of soils, water and plant nutrients, using crop varieties more tolerant of heat, droughts, floods and salinity (depending on circumstances), and adopting (flexible) diverse farm enterprises (Bennett et al., 2014). However, there is also a need to increase the capacity of institutions to enhance collective action, improve knowledge dissemination (e.g. about local weather information, planting dates, pest and disease control, water availability) and promote local adaptation planning. The role of private finance in supporting adaptation is just one aspect receiving research attention (Pauw et al., 2016).

Geographers are making major contributions to greater understanding of the adaptations to climate change made by farmers. For example, Smit and Skinner (2002) pioneered the formulation of a typology of potential adaptation measures. Whilst drawing primarily on the Canadian situation, this provided an excellent guide to the range of measures that could reduce the vulnerability of agricultural systems to risks related to climate change. The four principal categories recognized were: (i) technological developments, (ii) government programs and insurance, (iii) farm production practices, and (iv) farm financial management. 
Adaptations made by farmers may recognise that currently higher than 'normal' levels of GHGs already exist and, even if they levelled off today, they will still produce significant changes to the climate. Hence, there is a need to adapt to these changes. However, such a recognition does not necessarily underlay most on-farm changes as "many adaptations to climate change will be spontaneous actions to perceived and actual risks in the environment" (Adger, 2001, p. 921). Smit and Skinner noted that most adaptation options are modifications to on-going farm practices and public policy decision-making processes regarding changing climatic variability and extremes, and changes to non-climatic conditions (i.e. political, economic and social). Most commonly, adaptations are incremental, which involve short-term and small-scale actions to reduce losses or enhance the benefits of variations in climate. Less common are transformational changes, in which actions are adopted at a much larger scale or intensity than current actions, and/or comprise those that are new to a region. Transformations are generally based upon combinations of technological innovation, institutional reforms, behavioural shifts and cultural changes (Kuehne et al., 2017).

In an investigation into farmers' adaptations to climate change in South Australia, it was observed that most farmers interviewed did not believe in human-induced climate change. However, they acknowledged the occurrence of periods of excessive heat and/or drought and responded to these risks alongside others that affected their livelihoods, e.g., fluctuating prices, pests, changes to policy (Raymond \& Robinson, 2013; Robinson et al., 2018). The research concluded that farmers autonomously adapt to various risks, including those induced by climate variability. The types and levels of adaptation varied among individuals partly because of barriers to adaptation, which included limited communication and engagement processes established between formal institutions (e.g., government agencies) and communities of practice (e.g. farm systems groups). These institutions and communities are the keys to influencing what information about climate change the farmers receive and then what use is made of it in terms of changed on-farm practice. However, it was the communities of practice that were the principal influence on the farmers as it was through these that farmers shared best practice and could learn from initiators of innovation in their local area. They often followed the example of a valued neighbour or community leader whilst also adopting the advice of farm advisers such as agronomists.

Typical responses to excessive heat and/or drought in different parts of the world are to adopt moisture conservation practices, including adopting different pasture species and planting of shorter season crop varieties to combat shorter growing seasons (Allmaras et al., 2018). In addition, there may be longer-term adaptations, such as large-scale changes to the farming type, e.g. moving from cropping to sheep (Asseng \& Pannell, 2017), though economic motives might also be involved, such as responding to falling crop prices. However, the complexity of the decision-making process and the lack of specific focus on adapting to climate change by many farmers is summarised by Head et al. (2011, p. 1089) with reference to farmers facing drought in eastern Australia: "These 
farmers are not adapting to future conditions but are in continuous interplay among multiple temporalities, including memories of the past [...]. Capacities to deal with risk and uncertainty vary with a range of social and locational factors, tending to coalesce into patterns of vulnerability and resilience that offer strong predictors as to which households are most likely to be sustainable in the longer term." It should be noted, though, that in the face of drought, excessive heat and other climate-related challenges a perennial response worldwide is to quit farming (Bryant \& Garnham, 2018).

Agricultural systems in some parts of the world will be far more vulnerable to climate change than others. For example, the widespread increased reliance on irrigation around the Mediterranean has raised vulnerability, and there are already major strains on groundwater quality (Diaz et al., 2007; Iglesias et al., 2011; Lopez-Gunn et al., 2012). However, even farming systems dominated by small family farms using traditional methods may be quite resilient in the face of climate change. Observations of agricultural performance following extreme climatic events suggest that resiliency is closely related to high levels of on-farm biodiversity because this may offer greater flexibility in modifying the existing system (Altieri \& Nicholls, 2017). The biodiversity may reflect high levels of knowledge of local agri-ecology by the farmers and it is this knowledge that is utilized consistently to limit risk. Whilst climate change may represent new orders of magnitude of risk, the "tremendous diversity of domesticated crop and animal species maintained and enhanced by ingenuous soil, water, and biodiversity management regimes, nourished by complex traditional knowledge systems" (p. 36) may offer a flexible buffer against certain types of climate change, e.g. by increased use of drought-tolerant local varieties, water harvesting, mixed cropping, agroforestry, soil conservation practices and various traditional techniques (Stigter et al., 2005; Toledo \& Barrera-Bassols, 2008).

Recognition of the need to utilize the valuable information contained within traditional and experiential knowledge has grown considerably in recent years, giving rise to major changes in approaches to environmental management. This has seen a greater valuing of different forms of knowledge and rationality, and the coupling of approaches combining social and ecological systems (Burton \& Riley, 2018; Folke et al., 2005). This valuing/coupling has produced various approaches to environmental management under different labels, including adaptive co-management (Farhad et al., 2017), trans-disciplinary planning (Tress et al., 2006), community-based natural resource management (Robinson, 2006a, 2006b; Riehl et al., 2015), transitions management (Doyon et al., 2017); sustainability science (e.g. Wu, 2013) and sustainability education (Fazey et al., 2013).

Raymond et al. (2010, p.1767) list some of the elements held in common by these different approaches:

1) recognizing the need to integrate knowledge held by academic researchers from different disciplines and non-academics, such as land managers and the wider public; 
2) highlighting the need to build on different knowledges whilst developing shared theory, methods and new knowledge to promote common understanding of environmental management problems;

3) facilitating participatory, multi-level governance processes to both enhance the validity of knowledge elicited in research and to increase inclusiveness of stakeholders in decision making;

4) following iterative processes of knowledge creation, application, reflection, learning and feedback to science or decision making; and

5) attempting to integrate knowledge across a variety of spatial and temporal scales.

Yet, such integration often proves elusive. This reflects the many problems involved in developing policy or formulating plans when different types of knowledge, including that from farming communities, are involved. There are numerous ways that knowledge can be categorised and handled; it can be very difficult to bring different knowledges together; and applying 'integrated' knowledge may be difficult (Raymond et al., 2010, p. 1773; Feola et al., 2015). However, a first step is for those formulating policy to recognise that farmers' knowledge may be valuable and that processes need to be established for examining the validity and reliability of different knowledge claims so that it is not just science and so-called expert knowledge that drives decision making by policy makers.

Irrespective of the extent to which different types of knowledge are incorporated into policies aimed at adapting to or mitigating climate change, the many unknowns of climate change remain an unprecedented challenge for future generations. The nature of its interactions with globalizing forces are unpredictable and could present a serious threat to food security worldwide. How the associated problems are tackled and what local and regional responses emerge will undoubtedly form a major part of agricultural geographies in the coming decades. For geographers it is understanding of complex inter-relationships between the local, regional and global that will remain the key priority, requiring "ongoing research and critical debates to inform future policies aimed at addressing food insecurity, global hunger and uneven development" (Robinson and Carson, 2015, p. 240). This essay has attempted to provide a state-of-the-art summary of some of the current debates and can perhaps act as a starting point for further discussion regarding evolving relationships between globalization, agri-food systems and food security issues. 
Acknowledgments: I am most grateful to Dr. Valerià Paül Carril (Universidade de Santiago de Compostela) for encouraging me to write this review, and to delegates at annual conferences of the International Geographical Union's Commission on Sustainable Rural Systems for the stimulus their presentations, conversations and camaraderie have provided.

Authorship statement: The author declares no conflict of interest. 


\section{References}

Adger, W. N. (2001). Scales of governance and environmental justice for adaptation and mitigation of climate change. Journal of International Development, 13, 921-31. doi: http://dx.doi.org/10.1002/jid.833

Alkon, A. H. (2013). Food justice, food sovereignty and the challenge of neoliberalism. Paper presented at the international conference Food sovereignty: a critical dialogue, September 14-15, Yale University. Retrieved from hitps://www.tni.org/files/download/38_alkon_2013.pdf

Allen, P., FitzSimmons, M., Goodman, M., \& Warner, K. (2003). Shiffing plates in the agrifood landscape: the tectonics of alternative agrifood initiatives in California. Journal of Rural Studies, 19(1), 61-75. http://dx.doi.org/10.1016/50743-0167(02)00047-5

Allmaras, R. R., Wilkins, D. E., Burnside, O. C., \& Mulla, D. J. (2018). Agricultural technology and adoption of conservation practices. In F.J. Pierce (Ed.), Advances in soil and water conservation (pp. 99-158). London: Routledge.

Altieri, M. A., \& Nicholls, C.I. (2017). The adaptation and mitigation potential of traditional agriculture in a changing climate. Climatic Change, 140(1), 33-45. doi: http://dx.doi.org/10.1007/s10584-013-0909-y

Altman, A., \& Hasegawa, M. (Eds). (2017). Plant biotechnology and agriculture: Prospects for the 21st century. Cambridge, Mass.: Academic Press.

Almstedt, Å., Brouder, P., Karlsson, S., \& Lundmark, L. (2014). Beyond post-productivism: from rural policy discourse to rural diversity. European Countryside, 6(4), 297-306. doi: http://dx.doi.org/10.2478/euco-2014-0016

Amin, A. (Ed.) (1995). Post-Fordism, a reader. Oxford: Blackwell.

Anderson, K., \& Wittwer, G. (2015). Asia's evolving role in global wine markets. China Economic Review, 35, 1-14. doi: http://dx.doi.org/10.1016/i.chieco.2015.05.003

Anderson, M. (2015). A history of fair trade in contemporary Britain: From civil society campaigns to corporate compliance. London: Palgrave Macmillan.

Angelsen, A., Brockhaus, M., Duchelle, A.E., Larson, A., Martius, C., Sunderlin, W. D., Verchot, L., Wong, G., \& Wunder, S. (2017). Learning from REDDt: a response to Fletcher et al. Conservation Biology, 31(3), 718-720. doi: hitp://dx.doi.org/10.1111/cobi.12933

Antonelli, M., Siciliano, G., Turvani, M. E., \& Rulli, M. C. (2015). Global investments in agricultural land and the role of the EU: Drivers, scope and potential impacts. Land Use Policy, 47, 98111. hitp://dx.doi.org/10.1016/j.landusepol.2015.04.007 
Arce, A., \& Marsden, T. K. (2008). The social construction of international food: A new research agenda. In R. Munton (Ed.), The rural: Critical essays in human geography. London: Routledge.

Asseng, S., \& Pannell, D.J. (2013). Adapting dryland agriculture to climate change: Farming implications and research and development needs in Western Australia. Climatic Change, 118(2), 167-181. doi: http://dx.doi.org/10.1007/s10584-012-0623-1

Balogh, P., Békési, D., Gorton, M., Popp, J., \& Lengyel, P. (2016). Consumer willingness to pay for traditional food products. Food Policy, 61, 176-184. doi: http://dx.doi.org/10.1016/j.foodpol.2016.03.005

Baral, H., Keenan, R. J., Sharma, S. K., Stork, N. E., \& Kasel, S. (2014). Economic evaluation of ecosystem goods and services under different landscape management scenarios. Land Use Policy, 39, 54-64. doi: http://dx.doi.org/10.1016/j.landusepol.2014.03.008

Barnes, A., Sutherland, L. A., Toma, L., Matthews, K., \& Thomson, S. (2016). The effect of the Common Agricultural Policy reforms on intentions towards food production: Evidence from livestock farmers. Land Use Policy, 50, 548-558. http://dx.doi.org/10.1016/j.landusepol.2015.10.017

Bennett, E. M., Carpenter, S. R., Gordon, L. J., Ramakutty, N., Balvanera, P., Campbell, B. M., ... Spierenburg, M. (2014). Resilient thinking for a more sustainable agriculture. The Solutions Journal, 5(5), 65-75.

Bernstein, H. (2016). Agrarian political economy and modern world capitalism: the contributions of food regime analysis. Journal of Peasant Studies, 43(3), 611647. http://dx.doi.org/doi.org/10.1080/03066150.2015.1101456

Bieling, C., \& Plieninger, T. (Eds.) (2017). The science and practice of landscape stewardship. Cambridge: Cambridge University Press.

Blaikie, P. M. (1985). The political economy of soil erosion in developing countries. London: Longman.

Blaikie, P., Cannon, T., Davis, I., \& Wisner, B. (2014). At risk: Natural hazards, people's vulnerability and disasters. London \& New York: Routledge.

Bolsius, E. C., (ed.) (1993). The retreat: Rural land use and European agriculture. Amsterdam: Koninklijk Nederlands Aardrijkskundig Genootschap.

Borras Jr., S. M., Hall, R., Scoones, I., White, B., \& Wolford, W. (2011). Towards a better understanding of global land grabbing: an editorial introduction. Journal of Peasant Studies, 38(2), 209-216. doi: http://dx.doi.org/10.1080/03066150.2011.559005 
Bowers, J. K. (1985). British agricultural policy since the Second World War. Agricultural History Review, 33(1), 66-76.

Bowler, I. R. (Ed.), (1992). The geography of agriculture in developed market economies. London: Longman.

Browne, A. W., Harris, P.J., Hofny-Collins, A. H., Pasiecznik, N., \& Wallace, R. R. (2000). Organic production and ethical trade: definition, practice and links. Food Policy, 25(1), 69-89.

Bruce, A. (2016). The legacy of agrarian reform in Latin America: foundations of the fair-trade $\begin{array}{llll}\text { cooperative system. } \quad \text { Geography } & \text { Compass, } 12), \quad 485-498 .\end{array}$ doi: http://dx.doi.org/10.1111/gec3.12298

Bruckner, H. K. (2018). Beyond happy meat: Body mapping (dis)connections to animals in alternative food networks. Area, 50(3), 322-330. doi: http://dx.doi.org/10.1111/area. 12381

Bryant, L., \& Garnham, B. (2018). Farming exit and ascriptions of blame: The ordinary ethics of farming communities. Journal of Rural Studies, 62, 62-67. doi: http://dx.doi.org/10.1016/j.jrurstud.2018.07.004

Burke, F. P., Eckert, C., \& Davis S. (2014). Segmenting consumers' reasons for and against ethical consumption. European Journal of Marketing, 48(11/12), 2237-61. doi: http://dx.doi.org/10.1108/E|M-06-2013-0294

Burton, R.J. (2014). The influence of farmer demographic characteristics on environmental behaviour: A review. Journal of Environmental Management, 135, 19-26. doi: http://dx.doi.org/10.1016/j.jenvman.2013.12.005

Burton, R. J. (2004). Reconceptualising the 'behavioural approach' in agricultural studies: a sociopsychological perspective. Journal of Rural Studies, 20(3), 359-371. doi: http://dx.doi.org/10.1016/j.jrurstud.2003.12.001

Burton, R. J., \& Riley, M. (2018). Traditional Ecological Knowledge from the internet? The case of hay meadows in Europe. Land Use Policy, 70, 334-346. doi: http://dx.doi.org/10.1016/j.landusepol.2017.10.014

Byerlee, D., Falcon, W. P., \& Naylor, R. (2017). The tropical oil crop revolution: food, feed, fuel, and forests. Oxford: Oxford University Press.

Cairns, R., \& Krzywoszynska, A. (2016). Anatomy of a buzzword: The emergence of 'the waterenergy-food nexus' in UK natural resource debates. Environmental Science \& Policy, 64, 164-170. doi: http://dx.doi.org/10.1016/j.envsci.2016.07.007 
Campbell, B. M., Thornton, P., Zougmoré, R., Van Asten, P., \& Lipper, L. (2014). Sustainable intensification: What is its role in climate smart agriculture? Current Opinion on Environmental Sustainability, 8, 39-43. doi: http://dx.doi.org/10.1016/i.cosust.2014.07.002

Castree, N. (2015). Geography and global change science: Relationships necessary, absent, and possible. Geographical Research, 53(1), 1-15. doi: http://dx.doi.org/10.1111/1745$\underline{5871.12100}$

Catley, A., Lind, J., \& Scoones I. (Eds.) (2013). Pastoralism and development in Africa: Dynamic change at the margins. London: Earthscan.

Chaléard, J.-L., \& Charvet, J.-P. (2004). Géographie Agricole et Rurale. Paris: Benin.

Chen, H., López-Carr, D., Tan, Y., Xi, J. \& Liang, X. (2016). China's Grain for Green policy and farm dynamics: simulating household land-use responses. Regional Environmental Change, 16(4), 1147-1159. doi: http://dx.doi.org/10.1007/s10113-015-0826-x

Christophers, B. (2015). The limits to financialization. Dialogues in Human Geography, 5(2), 183200. doi: http://dx.doi.org/10.1177/2043820615588153

Clapp, J. (2017). Food self-sufficiency: Making sense of it, and when it makes sense. Food Policy, 66, 88-96. doi: http://dx.doi.org/10.1016/j.foodpol.2016.12.001

Clark, L. F., \& Hobbs, J. E. (2015). Innovations in international food assistance strategies and therapeutic food supply chains. In A. Schmitz, P.L. Kennedy \& T. G. Schmitz (Eds.), Food security in an uncertain world: An international perspective (pp. 111--28). Bningley, UK: Emerald Group Publishing Limited.

Cloke, P. J. (1989). Rural geography and political economy. In R. J. Peet \& N.J. Thrift (Eds.), New models in Geography (pp. 176-212). London: Routledge.

Coppock, J. T. (1976a). An agricultural atlas of England and Wales. London: Faber, second edition.

Coppock, J. T. (1976b). An agricultural atlas of Scotland. Edinburgh: John Donald.

Corbelle-Rico, E., Crecente-Maseda, R., \& Santé-Riveira, I. (2012). Multi-scale assessment and spatial modelling of agricultural land abandonment in a European peripheral region: Galicia (Spain), 1956-2004. Land Use Policy, 29(3), 493-501. doi: http://dx.doi.org/10.1016/j.landusepol.2011.08.008

Cotula, L. (2013). The Great African Land Grab? London: Zed Books.

Daniel, S. (2012). Situating private equity capital in the land grab debate. Journal of Peasant Studies, 39(3-4), 703-729. doi: http://dx.doi.org/10.1080/03066150.2012.674941 
Deere, C. D., \& Leon M. (2001). Institutional reform of agriculture under neoliberalism: the impact of the women's and indigenous movements. Latin American Research Review, 36(2), 31-6.

Defante, L. R., Vilpoux, O. F., \& Sauer, L. (2018). Rapid expansion of sugarcane crop for biofuels and influence on food production in the first producing region of Brazil. Food Policy, 79, 121-131. doi: http://dx.doi.org/10.1016/j.foodpol.2018.06.005

DeFries, R., Hansen, A., Turner, B. L., Reid, R., \& Liu, J. (2007). Land use change around protected areas: management to balance human needs and ecological function. Ecological Applications, 17(4), 1031-1038. doi: http://dx.doi.org/10.1890/05-1111

Deininger, K. (2011). Challenges posed by the new wave of farmland investment. Journal of Peasant Studies, 38(2), 217-247. doi: http://dx.doi.org/10.1080/03066150.2011.559007

De los Ríos, I., Rivera, M., \& García, C. (2016). Redefining rural prosperity through social learning in the cooperative sector: 25 years of experience from organic agriculture in Spain. Land Use Policy, 54, 85-94. doi: http://dx.doi.org/10.1016/j.landusepol.2016.02.009

Deng, X., Huang, J., Rozelle, S., Zhang, J., \& Li, Z. (2015). Impact of urbanization on cultivated land changes in China. Land Use Policy, 45, 1-7. doi: http://dx.doi.org/10.1016/j.landusepol.2015.01.007

Diaz, J. R., Weatherhead, E. K., Knox, J. W., \& Camacho, E. (2007). Climate change impacts on irrigation water requirements in the Guadalquivir river basin in Spain. Regional Environmental Change, 7(3), 149-159. doi: http://dx.doi.org/10.1007/s10113-007-0035-3

Dibden, J., Gibbs, D., \& Cocklin, C. (2013). Framing GM crops as a food security solution. Journal of Rural Studies, 29, 59-70. doi: http://dx.doi.org/10.1016/j.jrurstud.2011.11.001

Doyon, A., Coffey, B., Moloney, S., de Haan, F., \& Bosomworth, K. (2017). Exploring the contribution of transitions management to inform regional futures. Australasian Journal of Regional Studies, 23(3), 321.

Dunning, J. H. (Ed.) (2004). Making globalization good: The moral challenges of global capitalism. Oxford: Oxford University Press.

Eastin, J. (2018). Climate change and gender equality in developing states. World Development, 107, 289-305. doi: http://dx.doi.org/10.1016/j.worlddev.2018.02.021

Edelman, M. (2014). The next stage of the food sovereignty debate. Dialogues in Human Geography, 4(2), 182-184. doi: http://dx.doi.org/10.1177/2043820614537153

Epstein, G. (2002). Financialization, Rentier Interests, and Central Bank Policy. Paper prepared for the PERI Conference on "Financialization of the World Economy", December 7-8, 2001, University of Massachusetts, Amherst. 
Eriksen, S. H., Nightingale, A. J., \& Eakin, H. (2015). Reframing adaptation: The political nature of climate change adaptation. Global Environmental Change, 35, 523-533. doi: http://dx.doi.org/10.1016/j.gloenvcha.2015.09.014

Esteban Rodríguez, S. (2017). Cambios en las denominaciones de origen protegidas del sector del vino en España: movimientos entre mundos de producción. Boletín de la Asociación de Geógrafos Españoles, 74, 483-513. doi: http://dx.doi.org/10.21138/bage.2463

European Commission (2015). EU agriculture spending: Focused on results. European Commission Fact Sheet. Retrieved from http://ec.europa.eu/agriculture/cap-funding/pdf/capspending-092015_en.pdf

Fairhead, J., Leach, M., \& Scoones, I. (2012). Green grabbing: A new appropriation of nature? Journal of Peasant Studies, 39(2), 237-261. doi: http://dx.doi.org/10.1080/03066150.2012.671770

Farhad, S., Gual, M. A., \& Ruiz-Ballesteros, E. (2017). How does adaptive co-management relate to specified and general resilience? An approach from Isla Mayor, Andalusia, Spain. Land Use Policy, 67, 268-276. doi: http://dx.doi.org/10.1016/j.landusepol.2017.05.038

Farm Service Agency (FSA), United States Depoartment of Agriculture (USDA) (2016, May 5). USDA announces Conservation Reserve Program results [Release No. 0105.16] Retrieved from https://www.fsa.usda.gov/news-room/news-releases/2016/nr_20160505_rel_0105

Fazey, I., Evely, A. C., Reed, M. S., Stringer, L. C., Kruijssen, J., White, P. C., Newsham, A., Jin, L., Cortazzi, M., Phillipson, J., \& Blackstock, K. (2013). Knowledge exchange: a review and research agenda for environmental management. Environmental Conservation, 40(1), 19-36. doi: http://dx.doi.org/10.1017/S037689291200029X

Feola, G., Lerner, A. M., Jain, M., Montefrio, M. J. F., \& Nicholas, K. A. (2015). Researching farmer behaviour in climate change adaptation and sustainable agriculture: Lessons learned from five case studies. Journal of Rural Studies, 39, 74-84. doi: http://dx.doi.org/10.1016/j.jrurstud.2015.03.009

Ferry, N., \& Gatehouse, A. M. R. (Eds.) (2009). Environmental impact of Genetically Modified crops. Wallingford, UK: CAB International.

Fish, R., Winter, M., \& Lobley, M. (2014). Sustainable intensification and ecosystem services: new directions in agricultural governance. Policy Sciences, 47(1), 51-67. doi: http://dx.doi.org/10.1007/s11077-013-9183-0 
Fletcher, R., Dressler, W., Büscher, B. \& Anderson, Z. R. (2016). Questioning REDD+ and the future of market-based conservation. Conservation Biology, 30(3), 673-675. doi: http://dx.doi.org/10.1111/cobi. 12680

Folke, C., Hahn, T., Olsson, P., \& Nordberg, J. (2005). Adaptive governance of social-ecological systems. Annual Review of Environment and Resources, 30, 441-473. doi: http://dx.doi.org/10.1146/annurev.energy.30.050504.144511

Forrester, J., Cook, B., Bracken, L., Cinderby, S., \& Donaldson, A. (2015). Combining participatory mapping with Q-methodology to map stakeholder perceptions of complex environmental problems. Applied Geography, 56, 199-208. doi: http://dx.doi.org/10.1016/j.apgeog.2014.11.019

Friedma, H., \& McMichael, P. (1989). Agriculture and the state system: The rise and decline of national agricultures, 1870 to the present. Sociologia Ruralis, 29(2), 93-117. doi: http://dx.doi.org/10.1111/j.1467-9523.1989.tb00360.x

Gabriel, Y., \& Lang, T. (2015). The unmanageable consumer. London: Sage, 3rd ed.

Garnett, T., Appleby, M. C., Balmford, A., Bateman, I. J., Benton, T. G., Bloomer, P., Burlingame, B., Dawkins, M., Dolan, L., Fraser, D., \& Herrero, M. (2013). Sustainable intensification in agriculture: premises and policies. Science, 341(6141), 33-34.

Galdeano-Gómez, E., Pérez-Mesa, J. C. \& Godoy-Durán, Á. (2016). The social dimension as a driver of sustainable development: The case of family farms in southeast Spain. Sustainability Science, 11(2), 349-362. doi: http://dx.doi.org/10.1007/s11625-015-0318-4

Goodman, D. (2004). Rural Europe redux? Reflections on alternative agro-food networks and paradigm change. Sociologia Ruralis, 44(1), 3-16. doi: http://dx.doi.org/10.1111/j.14679523.2004.00258.x

Guadalupe, V., Sotta, E. D., Santos, V.F., Aguiar, L. J. G., Vieira, M., de Oliveira, C.P., \& Siqueira, J. V. N. (2018). REDD+ implementation in a high forest low deforestation area: Constraints on monitoring forest carbon emissions. Land Use Policy, 76, 414-421. doi: http://dx.doi.org/10.1016/j.landusepol.2018.02.015

Ghosh, J. (2010). The unnatural coupling: Food and global finance. Journal of Agrarian Change, 10(1), 72-86. doi: http://dx.doi.org/10.1111/j.1471-0366.2009.00249.x

Gu, J., Zhang, C., Vaz, A., \& Mukwereza, L. (2016). Chinese state capitalism? Rethinking the role of the state and business in Chinese development cooperation in Africa. World Development, 81, 24-34. doi: http://dx.doi.org/10.1016/j.worlddev.2016.01.001

Guthman, J. (2004). Agrarian dreams: The paradox of organic farming in California. Berkeley: University of California Press. 
Hall, R., Scoones, I., \& Tsikata, D. (2015). Africa's land rush: rural livelihoods and agrarian change. Melton, UK: James Currey.

Halpin, D. (Ed.) (2017). Surviving global change? Agricultural interest groups in comparative perspective. London: Routledge.

Harrison, R., Newholm, T., \& Shaw, D. (Eds.) (2005). The ethical consumer. Los Angeles: Sage.

Hartvigsen, M. (2014). Land reform and land fragmentation in Central and Eastern Europe. Land Use Policy, 36, 330-341. doi: http://dx.doi.org/10.1016/j.landusepol.2013.08.016

Head, L., Atchison, J., Gates, A., \& Muir, P. (2011). A fine-grained study of the experience of drought, risk and climate change among Australian wheat farming households. Annals of the Association of American Geographers, 101(5), 1089-1108. doi: http://dx.doi.org/10.1080/00045608.2011.579533

Heasman, M., \& Lang, T. (2015). Food wars: the global battle for mouths, minds and markets. London: Routledge.

Hellerstein, D. M. (2017). The US Conservation Reserve Program: the evolution of an enrollment mechanism. Land Use Policy, 63, 601-610. doi: http://dx.doi.org/10.1016/j.landusepol.2015.07.017

Helming, K., \& Wiggering, H. (Eds.), (2003). Sustainable development of multifunctional landscapes. Berlin: Springer.

Hernández Hernández, M., Moltó Mantero, E., \& Morote Seguido, A. (2018). Las redes agroalimentarias en la Montaña de Alicante, entre la tradición y las experctivas asociadas a la multifunctionalidad de los paisajes. In V. Paul Carrill, R. C. L. González, J. M. Trillo Santamaria \& F. Haslam McKenzie (Eds.), Infinite rural systems in a finite planet: Bridging gaps towards sustainability (pp. 43-50). Santiago de Compostela: Universidade de Santiago de Compostela Publicaciónes.

Hill, B. (2012). Farm incomes, wealth and agricultural policy: Filling the CAP's core information gap. Wallingford, UK \& Dambridge, MA: CABI, 4th edition.

Holmes, J. (2006). Impulses towards a multifunctional transition in rural Australia: gaps in the research agenda. Journal of Rural Studies, 22, 142-160. doi: htpp://dx.doi.org/10.1016/j.jurstud.2005.08.006

Iglesias, A., Mougou, R., Moneo, M., \& Quiroga, S. (2011). Towards adaptation of agriculture to climate change in the Mediterranean. Regional Environmental Change, 11(1), 159-166. doi: http://dx.doi.org/10.1007/s10113-010-0187-4 
International Service for the Acquisition of Agri-Biotech Applications (ISAAA) (2016). Biotech crop highlights in 2016. Retrieved from http://www.isaaa.org/resources/publications/pocketk/16/

Jaffee, D. (2014). Brewing justice: Fair trade coffee, sustainability, and survival. Berkeley: University of California Press.

Jarosz, L. (2014.) Comparing food security and food sovereignty discourses. Dialogues in Human Geography, 4(2), 168-181. doi: http://dx.doi.org/10.1177/2043820614537161

Jessop, B. (2006). Fordism, post-Fordism and the capitalist state. In B. Jessop \& N-L. Sum (Eds), Beyond the regulation approach: Putting capitalist economies in their place (pp. 90-119). Cheltenham: Edward Elgar.

Jiang, L., Deng, X., \& Seto, K. C. (2013). The impact of urban expansion on agricultural land use intensity in China. Land Use Policy, 35, 33-39. doi: http://dx.doi.org/10.1016/j.landusepol.2013.04.011

Juan, J. R. \& Díaz, A. R. (2016). Evolución del abandono de tierras de cultivo en la comarca oriental de la Región de Murcia. Boletín de la Asociación de Geógrafos Españoles, 71, 9-29. doi: http://dx.doi.org/10.21138/bage.2272

Kabisch, N., Frantzeskaki, N., Pauleit, S., Naumann, S., Davis, M., Artmann, M., ... Zaunberger, K. (2016). Nature-based solutions to climate change mitigation and adaptation in urban areas: perspectives on indicators, knowledge gaps, barriers, and opportunities for action. Ecology and Society, 21(2). doi: http://dx.doi.org/10.5751/ES-08373-210239

Kizos, T., Koshaka, R., Penker, M., Piatti, C., Vogl, C. R., \& Uchiyama, Y. (2017). The governance of geographical indications: Experiences of practical implementation of selected case studies in Austria, Italy, Greece and Japan. British Food Journal, 119(12), 2863-2879. doi: http://dx.doi.org/10.1108/BFJ-01-2017-0037

Kneafsey, M., Venn, L., \& Bos, E. (2017). Consuming rural connections: Tracing leeks back to their roots. In M. Miele, V. Higgins, H. Bjørkhaug \& M. Truninger (Eds.), Transforming the rural: Global processes and local futures (pp. 221-243). Bingley, UK: Emerald Publishing Limited.

Kuehne, G., Llewellyn, R., Pannell., D.J., Wilkinson, R., Dolling, P., Ouzman, J., \& Ewing, M. (2017). Predicting farmer uptake of new agricultural practices: a tool for research, extension and policy. Agricultural Systems, 156, 115-125. doi: http://dx.doi.org/10.1016/j.agsy.2017.06.007 Kull, M. (2014). European integration and rural development: Actors, institutions and power. London: Routledge.

Lam, K. N. T. (2016). Chinese State-Owned Enterprises in West Africa: Triple-embedded globalization. Abingdon, UK \& New York: Routledge. 
Lamb, A., Green, R., Bateman, I., Broadmeadow, M., Bruce, T., Burney, J., ... Goulding, K. (2016). The potential for land sparing to offset greenhouse gas emissions from agriculture. Nature Climate Change, 6(5), 488-492.

Lamine, C., \& Dawson, J. (2018). The agroecology of food systems: Reconnecting agriculture, food, and the environment. Agroecology and Sustainable Food Systems, 42(6), 629-636. doi: http://dx.doi.org/10.1080/21683565.2018.1432517

Lasanta Martínez, T., Vicente Serrano, S.M., \& Cuadrat Prats, J.M. (2005). Mountain Mediterranean landscape evolution caused by the abandonment of traditional primary activities: a study of the Spanish Central Pyrenees. Applied Geography, 25(1), 47-65.

Lastra-Bravo, X.B., Hubbard, C., Garrod, G., \& Tolón-Becerra, A. (2015). What drives farmers' participation in EU agri-environmental schemes? Results from a qualitative meta-analysis. Environmental Science \& Policy, 54, 1-9. doi: http://dx.doi.org/10.1016/j.envsci.2015.06.002 Lawrence, G. (2015). Defending financialization. Dialogues in Human Geography, 5(2), 201205. doi: http://dx.doi.org/10.1177/2043820615588155

Lawrence, G., Lyons, K., \& Wallington, T. (Eds.) (2011). Food security, nutrition and sustainability. London: Earthscan.

Lazarus, E. D. (2014). Land grabbing as a driver of environmental change. Area, 46(1), 74-82. doi: http://dx.doi.org/10.1111/area.12072

Lekakis, E.J. (2013). Coffee activism and the politics of fair trade and ethical consumption in the global north: political consumerism and cultural citizenship. London: Palgrave Macmillan.

Lipper, L., Thornton, P., Campbell, B. M., Baedeker, T., Braimoh, A., Bwalya, M., ... Hottle, R. (2014). Climate-smart agriculture for food security. Nature Climate Change, 4(12), 1068-1072. doi: http://dx.doi.org/10.1038/nclimate2437

Liu, Y., \& Li, Y. (2017). Revitalize the world's countryside. Nature, 548(7667), 275-277.

Liu, Y., Liu, J., \& Zhou, Y. (2017). Spatio-temporal patterns of rural poverty in China and targeted poverty alleviation strategies. Journal of Rural Studies, 52, 66-75. doi: http://dx.doi.org/10.1016/j.jrurstud.2017.04.002

Liu, Y. (2018, July 29), Opinion: How to revitalize the countryside in China? In News CGTN. https://news.cgtn.com/news/3d3d414d7749544d79457a6333566d54/share_p.html

Liu, Y., Liao, L., Long, H., \& Qin, J. (2015). Effects of land use transitions on ecosystem services value - a case study of Hunan province. Geographical Research, 34(4), 691-700. 
Liu, Y., Fang, F., \& Li, Y. (2014). Key issues of land use in China and implications for policy making. Land Use Policy, 40, 6-12. doi: http://dx.doi.org/10.1016/j.landusepol.2013.03.013

Lockie, S. (2008). Conversion or co-option? The implications of 'mainstreaming' for producer and consumer agency with fair trade networks. In CR Farnworth, J Jiggins \& EV Thomas (Eds.), Creating food futures: trade, ethics and the environment (pp. 215-227). Aldershot: Gower Publishing.

Long, H., Liu, Y., Hou, X., Li, T., \& Li, Y. (2014). Effects of land use transitions due to rapid urbanization on ecosystem services: Implications for urban planning in the new developing area of China. Habitat International, 44, 536-544. doi: http://dx.doi.org/10.1016/j.habitatint.2014.10.011

Lopez-Gunn, E., Zorrilla, P., Prieto, F., \& Llamas, M.R. (2012). Lost in translation? Water efficiency in Spanish agriculture. Agricultural Water Management, 108, 83-95. doi: http://dx.doi.org/10.1016/j.agwat.2012.01.005

McGuire, J. M., Morton, L. W., Arbuckle Jr, J. G., \& Cast, A.D. (2015). Farmer identities and responses to the social-biophysical environment. Journal of Rural Studies, 39, 145-155. doi: http://dx.doi.org/10.1016/j.jrurstud.2015.03.011

Mclntyre, B. D., Herren, H. R., Wakhungu, J., \& Watson, R. T. (2009). Agriculture at a crossroads: synthesis report. Washington DC: International Assessment of Agricultural Knowledge, Science and Technology for Development (IAASTD) Report, Island Press.

McMichael, P. (2014). Rethinking land grab ontology. Rural Sociology, 79(1), 34-55. doi: http://dx.doi.org/10.1111/ruso. 12021

McMichael, P. (2013). Food regimes and agrarian questions: Agrarian change and peasant studies. Black Point, NS: Fernwood.

Magnan, A. (2015). The financialization of agri-food in Canada and Australia: Corporate farmland and farm ownership in the grains and oilseed sector. Journal of Rural Studies, 41, 1-12. doi: http://dx.doi.org/10.1016/j.jurstud.2015.06.007

Majoral, R. (1979a). La utilización del suelo agrícola en Catalunya. Barcelona: Universitat de Barcelona.

Majoral, R. (1979b). L'extensió actual de la vinya i l'oliveira a Catalunya. In J.M. Panareda \& J.M. Rabella (Eds.), Aportacions en homentage al geògraf Salvador Llobet (pp. 127-142). Barcelona: Department de Geografia, Universitat de Barcelona.

Marsden, T. K. (2011). Farming and agrifood in Wales: a new agenda. In P. Milbourne (Ed.), Rural Wales in the twenty-first century: Society, economy and environment (pp. 189-214). Cardiff: University of Wales Press. 
Marsden, T. K. (1988). Exploring political economy approaches in agriculture. Area, 20, 315-321.

Marsden, T. K., Campbell, H., Carolan, M., Le Heron, R., \& Lewis, N. (2016). Assembling generative approaches in agrifood research. In R. Le Heron, H. Campbell, N. Lewis \& M. Carolan (Eds.), Biological Economies: Experimentation and the politics of agrifood frontiers (pp. 1-20). London \& New York: Routledge.

Margulis, M.E. (2014). Trading out of the global food crisis? The World Trade Organization and the geopolitics of food security. Geopolitics, 19(2), 322-350. doi: http://dx.doi.org/1080/14650045.2014.920233

Massot-Marti, A. (2003). Le paradigme multifonctionnel: outil et arme dans la renégociation de la PAC. Économie rurale, 273(1), 30-44. doi: http://dx.doi.org/10.3406/afdi.2006.3935

Mather, A.S., Hill, G., \& Nijnik, M. (2006). Post-productivism and rural land use: cul de sac or challenge for theorization? Journal of Rural Studies, 22(4), 441-455. doi: http://dx.doi.org/10.1016/j.jrurstud.2006.01.004

Meadows, M. (2011). Sustainable development and GM food: An analysis of the relationship between the genetic modification of crops and the varieties of sustainable development. Manchester, UK: Revive Publications.

Melendez-Pastor, I., Hernández, E. I., Navarro-Pedreño, J., \& Gomez, I. (2014). Socio-economic factors influencing land cover changes in rural areas: The case of the Sierra de Albarracín (Spain). Applied Geography, 52, 34-45. doi: http://dx.doi.org/10.1016/j.apgeog.2014.04.013

Milbourne, P. (2016). Rural Geography. In D. Richardson, N. Castree, M. F. Goodchild, A. Kpobayashi, W. Liu \& R. A. Marston (Eds.), International Encyclopedia of Geography: People, the Earth, Environment and Technology (pp.1-17). Chichester, UK \& New York: Wiley-Blackwell.

Molinero Hernando, F., Baraja Rodríguez, E., \& Alario Trigueros, E. (2016). Incidencia de la PAC en la dinamíca de las estructuras agrarias y en la diversificacíon funcional del camp de Castill y Leon. In A. R. Ruiz Pulpón, M. A. Serrano de la Cruz Santos-Olmo \& J. J. Plaza Tabasco (Eds.), Treinta años de Política Agraria Común en España. Agricultura y multifuncionalidad en el contexto de la nueva ruralidad. Ciudad Real: Asociación de Geógrafos Españoles (Grupo de Geografía Rural), pp. 97-110.

Moreira, M. B. (2017). Impacts of financialization on agricultural and rural investment: Lessons from the Portuguese case. In M. Miele, V. Higgins, H. Bjørkhaug \& M. Truninger (Eds.), Transforming the rural: Global processes and local futures (pp. 25-44). Bingley, UK: Emerald Publishing Limited. 
Morris, C. \& Evans, N. (2004). Agricultural turns, geographical turns: retrospect and prospect. Journal of Rural Studies, 20(1), 95-111. doi: http://dx.doi.org/10.1016/S0743-0167(03)00041-X

O'Connor, N., Farag, K., \& Baines, R. (2016). What is food poverty? A conceptual framework. British Food Journal, 118(2), 429-449. doi: http://dx.doi.org/10.1108/BFl-06-2015-0222

Oostindie, H., Van Broekhuizen, R., De Roest, K., Belletti, G., Arfini, F., Menozzi, D., \& Hees, E. (2016). Sense and non-sense of local-global food chain comparison, empirical evidence from dutch and Italian pork case studies. Sustainability, 8(4), 319. doi: http://dx.doi.org/10.3390/su8040319

Ouma, S. (2016). From financialization to operations of capital: Historicizing and disentangling the finance-farmland-nexus. Geoforum, 72 , 82-93. doi: http://dx.doi.org/10.1016/j.geoforum.2016.02.003

Paül, V., \& McKenzie, F.H. (2013). Peri-urban farmland conservation and development of alternative food networks: Insights from a case-study area in metropolitan Barcelona (Catalonia, Spain). Land Use Policy, 30(1), 94-105. doi: http://dx.doi.org/10.1016/j.landusepol.2012.02.009

Pauw, W. P., Klein, R.J., Vellinga, P., \& Biermann, F. (2016). Private finance for adaptation: Do private realities meet public ambitions? Climatic Change, 134(4), 489-503. doi: http://dx.doi.org/10.1007/s10584-015-1539-3

Pearce, J., \& Witten, K. (Eds.) (2016). Geographies of obesity: Environmental understandings of the obesity epidemic. London \& New York: Routledge.

Peng, J., Zhao, M., Guo, X., Pan, Y., \& Liu, Y. (2017). Spatial-temporal dynamics and associated driving forces of urban ecological land: A case study in Shenzhen City, China. Habitat International, 60, 81-90. doi: http://dx.doi.org/10.1016/j.habitatint.2016.12.005

Perkins, H. C., Mackay, M., \& Espiner, S. (2015). Putting pinot alongside merino in Cromwell District, Central Otago, New Zealand: Rural amenity and the making of the global countryside. Journal of Rural Studies, 39, 85-98. doi: http://dx.doi.org/10.1016/j.jrurstud.2015.03.010

Petersen, B., \& Snapp, S. (2015). What is sustainable intensification? Views from experts. Land Use Policy, 46, 1-10. doi: http://dx.doi.org/10.1016/j.landusepol.2015.02.002

Porter, J., Costanza, R., Sandhu, H., Sigsgaard, L., \& Wratten, S. (2009). The value of producing food, energy, and ecosystem services within an agro-ecosystem. Ambio, 38(4), 186-193. doi: http://dx.doi.org/10.1579/0044-7447-38.4.186 
Potschin, M., \& Haines-Young, R. (2016). Defining and measuring ecosystem services. In: $M$. Potschin, R. Haines-Young, R. Fish \& R.K. Turner (Eds.), Routledge handbook of ecosystem services (pp. 53-72). London \& New York: Routledge.

Pretty, J. (2002). Agri-culture: Reconnecting people, land and nature. London: Earthscan.

Pritchard, B., Dixon, J., Hull, E., \& Choithani, C. (2016). 'Stepping back and moving in': the role of the state in the contemporary food regime. Journal of Peasant Studies, 43(3), 693-710. doi: http://dx.doi.org/10.1080/03066150.2015.1136621

Raphaely, T., \& Marinova, D. (Eds.) (2015). Impact of meat consumption on health and environmental sustainability. Hershey, Penn: IGI Global.

Raymond, C. M., Reed, M., Bieling, C., Robinson, G. M., \& Plieninger, T. (2016a). Integrating different understandings of landscape stewardship into the design of agri-environmental schemes. Environmental Conservation, 43(4), 350-358. doi: http://dx.doi.org/10.1017/S037689291600031X

Raymond, C. M., Bieling, C., Fagerholm, N., Martin-Lopez, B., \& Plieninger, T. (2016b). The farmer as a landscape steward: comparing local understandings of landscape stewardship, landscape values, and land management actions. Ambio, 45, 173-184. doi: http://dx.doi.org/10.1007/s13280-015-0694-0

Raymond, C. M., Fazey, I., Reed, M. S., Stringer, L. C., Robinson, G. M., \& Evely, A. C. (2010). Integrating local and scientific knowledge for environmental management: From products to processes, Journal of Environmental Management, 91(8), 1766-1777. doi: http://dx.doi.org/10.1016/j.jenvman.2010.03.023

Raymond, C. M., \& Robinson, G. M. (2013). Factors affecting rural landholders' adaptation to climate change: Insights from formal institutions and communities of practice. Global Environmental Change, 23(1), 103-114. doi: http://dx.doi.org/10.1016/j.gloenvcha.2012.11.004

Renting, H., Rossing, W. A. H., Groot, J. C. J., van der Ploeg, J. D., Laurent, C., Perraud, D., van Ittersum, M. K. (2009). Exploring multifunctional agriculture. A review of conceptual approaches and prospects for an integrative transitional framework. Journal of Environmental Management, 90(Suppl 2), S112-23. doi: http://dx.doi.org/10.1016/j.jenvman.2008.11.014

Rescia, A. J., Pons, A., Lomba, I., Esteban, C. \& Dover, J. W. (2008). Reformulating the socialecological system in a cultural rural mountain landscape in the Picos de Europa region (northern Spain). Landscape and Urban Planning, 88(1), 23-33. 
Riehl, B., Zerriffi, H., \& Naidoo, R. (2015). Effects of community-based natural resource management on household welfare in Namibia. PLoS One, 10(5), e0125531. doi: http://dx.doi.org/10.1371/journal.pone.0125531

Rignall, K., \& Atia, M. (2017). The global rural: Relational geographies of poverty and uneven development. Geography Compass, 11(7), e12322. Retrieved from https://doi.org/10.1111/gec3.12322

Riley, M. (2016). How does longer term participation in agri-environment schemes [re] shape farmers' environmental dispositions and identities? Land Use Policy, 52, 62-75. doi: http://dx.doi.org/10.1016/j.landusepol.2015.12.010

Riley, M. (2011). Turning farmers into conservationists? Progress and prospects. Geography Compass, 5(6), 369-389. doi: http://dx.doi.org/10.1111/j.1749-8198.2011.00423.x

Ríos-Núñez, S. M., \& Coq-Huelva, D. (2015). The transformation of the Spanish livestock system in the second and third food regimes. Journal of Agrarian Change, 15(4), 519-540. doi: http://dx.doi.org/10.1111/joac. 12088

Robinson, D. F. (2010). Confronting Biopiracy: Challenges, Cases and International Debates. London: Earthscan.

Robinson, G. M. (2018a). Globalization of agriculture. Annual Review of Resource Economics, 10. doi: http://dx.doi.org/10.1146/annurev-resource-100517-023303

Robinson, G. M. (2018b). Agricultural Geography. In D. Richardson, N. Castree, M. F. Goodchild, A. Kpobayashi, W. Liu \& R.A. Marston (Eds.). International Encyclopedia of Geography: People, the Earth, Environment and Technology. Chichester, UK \& New York: Wiley-Blackwell. doi: http://dx.doi.org/10.1002/9781118786352.wbieg0590.pub2

Robinson, G. M. (2009). Towards sustainable agriculture: Current debates. Geography Compass, 3(5), 1757-1773. doi: http://dx.doi.org/10.1111/j.1749-8198.2009.00268.x

Robinson, G. M. (2006a). Ontario's environmental farm plan: evaluation and research agenda. Geoforum, 37(5), 859-873. doi: http://dx.doi.org/10.1016/j.geoforum.2005.05.002

Robinson, G. M. (2006b). Canada's environmental farm plans: trans-Atlantic perspectives on agrienvironmental schemes. Geographical Journal, 172(3), 206-218. doi: http://dx.doi.org/10.1111/j.1475-4959.2006.00207.x

Robinson, G.M. (2004). Geographies of agriculture: Globalisation, restructuring and sustainability. Harlow, UK: Pearson. 
Robinson, G. M. (1994). The greening of agricultural policy: Scotland's Environmentally Sensitive Areas (ESAs). Journal of Environmental Planning and Management, 37, 215-225. doi: http://dx.doi.org/10.1080/09640569408711971

Robinson, G. M., Bardsley, D. K., Raymond, C. M., Underwood, T., Moskwa, E. C., ... Bardsley, A. M. (2018). Adapting to climate change: Lessons from farmers and peri-urban fringe residents in South Australia. Environments, 5(3). doi: http://dx.doi.org/10.3390/environments5030040

Robinson, G. M., \& Carson, D. A. (2016). Resilient communities: Transitions, pathways and resource-fulness. Geographical Journal, 182(2), 114-22. doi: http://dx.doi.org/10.1111/geoj.12144

Robinson, G. M., \& Carson, D. A. (2015). The globalisation of agriculture: Introducing the Handbook. In G. M. Robinson \& D. A. Carson (Eds.), Handbook on the globalisation of agriculture (pp. 1-30). Cheltenham, UK \& Northampton, Mass: Edward Elgar Publishing.

Robinson, G. M., \& Song. B. (forthcoming). Rural transformation: Cherry growing in Shaanxi Province, China and the Adelaide Hills, South Australia. Journal of Geographic Sciences.

Rosset, P. (2013). Re-thinking agrarian reform, land and territory in La Via Campesina. J. Peasant Studies, 40(4), 721-775. doi: http://dx.doi.org/10.1080/03066150.2013.826654

Sal, A. G., \& García, A. G. (2007). A comprehensive assessment of multifunctional agricultural land-use systems in Spain using a multi-dimensional evaluative model. Agriculture, Ecosystems \& Environment, 120(1), 82-91. doi: http://dx.doi.org/10.1016/j.agee.2006.06.020

Schmidt, M. \& Pearson, O. (2016). Pastoral livelihoods under pressure: Ecological, political and socioeconomic transitions in Afar (Ethiopia). Journal of Arid Environments, 124, 22-30. doi: http://dx.doi.org/10.1016/j.jaridenv.2015.07.003

Scoones, I., Leach, M., \& P. Newell (Eds.) (2015). Pathways to sustainability: The politics of green transformations. London: Earthscan.

Serra, P., Vera, A., Tulla, A. F., \& Salvati, L. (2014). Beyond urban-rural dichotomy: Exploring socio-economic and land-use processes of change in Spain (1991-2011). Applied Geography, 55, 71-81. doi: http://dx.doi.org/10.1016/j.apgeog.2014.09.005

Serrano, J. A. S. (2017). Las ayudas agrarias y sus repercusiones sobre la agricultura familiar en la última reforma de la Política Agraria Común (2014-2020) de la Unión Europea: ¿Cambiar para que todo siga igual? Boletín de la Asociación de Geógrafos Españoles, 74, 161-183. doi: http://dx.doi.org/10.21138/bage.2449

Servon, L. J., \& Pink, S. (2015). Cittaslow: going glocal in Spain. Journal of Urban Affairs, 37(3), 327-340. doi: http://dx.doi.org/10.1111/juaf.12169 
Shi, T., Liu, Y., Zhang, L., Hao, L., \& Gao, Z. (2014). Burning in agricultural landscapes: An emerging natural and human issue in China. Landscape Ecology, 29(10), 1785-1798.

Shortall, S. (2015). Gender mainstreaming and the common agricultural policy. Gender, Place \& Culture, 22(5), 717-730. doi: http://dx.doi.org/10.1080/0966369X.2014.939147

Simoncini, R. (2009). Developing an integrated approach to enhance the delivering of environmental goods and services by agro-ecosystems. Regional Environmental Change, 9(3), 153-167. doi: http://dx.doi.org/10.1007/s10113-008-0052-x

Smit, B., \& Skinner, M. W. (2002). Adaptation options in agriculture to climate change: a typology. Mitigation and Adaptation Strategies for Global Change, 7(1), 85-114.

Song, B., Robinson, G.M., \& Zhou, Z. (2017). Agricultural transformation and ecosystem services: A case study from Shaanxi Province, China. Habitat International, 69, 114-125. doi: http://dx.doi.org/10.1016/j.habitatint.2017.09.008

Song, X., Peng, C., Zhou, G., Jiang, H., \& Wang, W. (2014). Chinese Grain for Green Program led to highly increased soil organic carbon levels: A meta-analysis. Scientific Reports, 4, 4460. doi: http://dx.doi.org/10.1038/srep04460

Stigter, C., Dawei, Z., Onyewotu, L., \& Xurong, M. (2005). Using traditional methods and indigenous technologies for coping with climate variability. Climate Change, 70, 255-271. doi: http://dx.doi.org/10.1007/s10584-005-5949-5

Su, C., Fu, B., Wei, Y., Lü, Y., Liu, G., Wang, D., Mao, K., \& Feng, X. (2012). Ecosystem management based on ecosystem services and human activities: A case study in the Yanhe watershed. Sustainability Science, 7(1), 17-32. doi: http://dx.doi.org/10.1007/s11625-011$\underline{0145-1}$

Sulieman, H. M. \& Ahmed, A.G.M. (2017). Mapping the pastoral migratory patterns under land appropriation in East Sudan: the case of the Lahaween Ethnic Group. Geographical Journal, 183(4), 386-399. doi: http://dx.doi.org/10.1111/geoj.12175

Swan, S. H., Hadley, S., \& Cichon, B. (2010). Crisis behind closed doors: global food crisis and local hunger. Journal of Agrarian Change, 10(1), 107-18. doi: http://dx. doi.org/10.1111/j.1471$\underline{0366.2009 .00252 . x}$

Tang, Q., Bennett, S. J., Xu, Y., \& Li, Y. (2013). Agricultural practices and sustainable livelihoods: Rural transformation within the Loess Plateau, China. Applied Geography, 41, 15-23. doi: http://dx.doi.org/10.1016/j.apgeog.2013.03.007

Thompson, J.A. (2016). Genetically modified crops in South Africa. In S. De Buck, I. Ingelbrecht, M. Heijde, \& M. van Montagu (Eds.), Innovative farming and forestry across the emerging world: 
the role of genetically modified crops and trees (pp. 73-80). Gent, Belgium: International Industrial Biotechnology Network (IIBN).

Thorsøe, M., \& Kjeldsen, C. (2016). The constitution of trust: Function, configuration and generation of trust in alternative food networks. Sociologia Ruralis, 56(2), 157-175. doi: http://dx.doi.org/10.1111/soru. 12082

Tilman, D., Clark, M., Williams, D. R., Kimmel, K., Polasky, S., \& Packer, C. (2017). Future threats to biodiversity and pathways to their prevention. Nature, 546(7656), 73-81. doi: http://dx.doi.org/10.1038/nature22900

Tilzey, M., \& Potter, C. (2008). Productivism versus Post-Productivism? Modes of agrienvironmental governance in Post-Fordist agricultural transitions. In G.M. Robinson (Ed.), Sustainable rural systems: Sustainable agriculture and rural communities (pp. 41-66). Aldershot \& Burlington, VT: Ashgate.

Tittonell, P. (2014). Ecological intensification of agriculture-sustainable by nature. Current Opinion on Environmental Sustainability, 8, 53-61. doi: http://dx.doi.org/10.1016/j.cosust.2014.08.006 Toledo, V. M., \& Barrera-Bassols, N. (2008). La memoria biocultural: la importancia ecológica de las sabidurías tradicionales. Barcelona: Icaria editorial.

Tress, B., Tress, G., \& Fry, G. (2006). Defining concepts and the process of knowledge production in integrative research. In: B. Tress, G. Tress, G. Fry \& P. Opdam, (Eds.), From landscape research to landscape planning: Aspects of integration, education and Application (pp. 13-26). Dordrecht, The Netherlands: Springer.

US Food Sovereignty Alliance (2018). Food sovereignty. Retrieved from http://usfoodsovereigntyalliance.org/what-is-food-sovereignty/

van Caenegem, W., \& Cleary, J. A. (Eds.) (2017). The importance of place: Geographical indications as a tool for local and regional development. New York: Springer.

Walford, N. S. (2003). Productivism is allegedly dead, long live productivism. Evidence of continued productivist attitudes and decision making in South-East England. Journal of Rural Studies, 19(4), 491-502. doi: http://dx.doi.org/10.1016/S0743-0167(03)00030-5

Wang, J., Peng, J., Zhao, M., Liu, Y. \& Chen, Y. (2017). Significant trade-off for the impact of Grain-for-Green programme on ecosystem services in North-Western Yunnan, China. Science of The Total Environment, 574, 57-64. doi: http://dx.doi.org/10.1016/j.scitotenv.2016.09.026

Wang, Y., \& Zhou, Z.X. (2014). Evaluation of urban agricultural land use efficiency based on urban agricultural multi-functionality - A case study of Xi'an City. Economic Geography, 34(7), 129-134. 
Watts, G., Battarbee, R. W., Bloomfield, J. P., Crossman, J., Daccache, A., Durance, I., ... Hess, T. (2015). Climate change and water in the UK-past changes and future prospects. Progress in Physical Geography, 39(1), 6-28. doi: http://dx.doi.org/10.1177/0309133314542957

White, B., Saturnino, M., Borras, M., Hall, R., Scoones, I., \& Wolford W. (2012). The new enclosures: critical perspectives on corporate land deals. Journal of Peasant Studies, 39(3-4), 619-647. doi: http://dx.doi.org/10.1080/03066150.2012.691879

Wiebe, K., Lotze-Campen, H., Sands, R., Tabeau, A., van der Mensbrugghe, D., Biewald, A., ... Müller, C. (2015). Climate change impacts on agriculture in 2050 under a range of plausible socioeconomic and emissions scenarios. Environmental Research Letters, 10(8), 085010. doi: http://dx.doi.org/10.1088/1748-9326/10/8/085010

Wilson, B. R. (2010). Indebted to fair trade? Coffee and crisis in Nicaragua. Geoforum, 41, 8492. doi: http://dx.doi.org/10.1016/j.geoforum.2009.06.008

Wilson, G. A. (2010). Multifunctional 'quality'and rural community resilience. Transactions of the Institute of British Geographers, 35(3), 364-38. doi: http://dx.doi.org/10.1111/j.1475$\underline{5661.2010 .00391 . x}$

Wilson, G. A. (2009). The spatiality of multifunctional agriculture: A human geography perspective. Geoforum, 40(2), 269-280. doi: http://dx.doi.org/10.1016/j.geoforum.2008.12.007

Wilson, G. A. (2008). From 'weak'to 'strong'multifunctionality: Conceptualising farm-level multifunctional transitional pathways. Journal of Rural Studies, 24(3), 367-383. doi: http://dx.doi.org/10.1016/j.jrurstud.2007.12.010

Wilson, G. A. (2007). Multifunctional agriculture: a transition theory perspective. Wallingford: CABI.

Wilson, G. A. (2001). From productivism to post-productivism... and back again? Exploring the (un)changed natural and mental landscapes of European agriculture. Transactions of the Institute of British Geographers, 26(1), 77-102. doi: http://dx.doi.org/10.1111/1475-5661.00007

Wood, S. A, Karp, D. S., DeClerck, F., Kremen, C., Palm, C. A, \& Naeem, S. (2015) Functional traits in agriculture: agrobiodiversity and ecosystem services. Trends in Ecology and Evolution, 30, 531-539. doi: http://dx.doi.org/10.1016/j.tree.2015.06.013

Woods, M. (2005). Contesting rurality: Politics in the British countryside. London: Taylor \& Francis.

Wu, J. (2013). Landscape sustainability science: ecosystem services and human well-being in changing landscapes. Landscape Ecology, 28(6), 999-1023. doi: http://dx.doi.org/10.1007/s10980-013-9894-9 
Xiao, J. (2014). Satellite evidence for significant biophysical consequences of the "Grain for Green" Program on the Loess Plateau in China. Journal of Geophysical Research: Biogeosciences, 119(12), 2261-2275. doi: http://dx.doi.org/10.1002/2014JG002820

Yuan, M., Seale Jr., J. L., Wahl, T., \& Bai, J. (2018) The changing dietary patterns and health issues in China, China Agricultural Economic Review. doi: http://dx.doi.org/10.1108/CAER-12-2017$\underline{0254}$

Zhao, Y. (2013). China's disappearing countryside: Towards sustainable land governance for the poor. Farnham, UK \& Burlington, VT: Ashgate.

Zhu, W. F., Wang, S. L., \& Caldwell, C. D. (2010). Agroecosystem service and its managerial essence. Chinese Journal of Eco-agriculture, 18(4), 889-896 [in Chinese]. 